15.

\title{
SENATORI IZ SPLITA: SUOČAVANJE \\ S KRIZOM JUGOSLAVIJE I \\ JUGOSLAVENSTVA
}

\section{Stjepan Matković}

UDK: 328(497.1):32-05(497.58)“193“

Izvorni znanstveni članak

Sažetak: Autor u tekstu obrađuje djelovanje političara iz Splita i okolice (Budislav Grga Angjelinović, Uroš Desnica, Petar Gjirlić, Frano Ivanišević i Ivan Majstrović) koji su nakon uspostave šestosiječanjskog režima ušli imenovanjem ili izborom u Senat Kraljevine Jugoslavije na temelju čl. 32 Ustava. Riječ je o pripadnicima raznih političkih struja jugoslavenske orijentacije čiji javni nastup tijekom 1930-ih doživljava novu afirmaciju predstavljanjem Primorske banovine u Senatu. S druge strane, analiza njihovih nastupa pokazuje razmimoilaženja u pristupu prevladavanju državne krize i preispitavanju nacionalnog identiteta, pri čemu se prelamaju utjecaji lokalnih prilika i osobni pogledi pojedinih senatora u skladu s njihovim svjetonazorima.

Ključne riječi: Split, senatori, jugoslavenstvo, integralizam

\section{UVODNE NAPOMENE}

II

akon završetka Prvoga svjetskog rata, raspada Austro-Ugarske Monarhije i stvaranja Kraljevstva SHS Split je stekao u temeljito izmijenjenim prilikama zamjetno drugačiji značaj u odnosu na ranije razdoblje. Koristeći svoj istaknuti položaj u središnjem dijelu istočnojadranske obale, činjenicu da je već od ranih 1880-ih nakon pada autonomaške uprave preuzeo ulogu predvodnika hrvatskoga narodnog pokreta u dalmatinskoj krunovini i istovremeno uzimajući u obzir ishod postupnog rješavanja jadranskog pitanja kojim su u korist Italije izgubljeni znatni dijelovi pripadajućeg teritorija, postao je glavno središte upravnog, gospodarskog i kulturnog života Dalmacije, ali i najveća pomorska luka nove države koja joj je trebala omogućiti veće otvaranje prema svijetu. ${ }^{1}$ Takav izmijenjeni položaj je u velikoj mjeri utjecao i na politička kretanja, koja su postala iznimno dinamična.

1 Za najzaokruženiji pregled širih kretanja u međuratnom Splitu s mnogo statističkih pokazatelja i temeljitom analizom političkih kretanja vidi: Aleksandar JAKır, Dalmatien zwischen den Weltkriegen, München 1999. 
Još na početku 20. stoljeća u Splitu je sve više do izražaja dolazila skupina političara koja je u novim okolnostima zaoštravanja unutarnje krize dualističkog uređenja u Monarhiji i rasta napetosti između dvaju blokova europskih velesila radi izlaska iz vlastitog podređenog položaja zagovarala primjenu već otprije lansirane ideje narodnog jedinstva Hrvata i Srba. $S$ afirmacijom politike "novog kursa“ ta je koncepcija dobila obnovljen zamah i time čvršće poticala povezivanje njezinih zagovornika na jugu Monarhije, a istovremena smjena na prijestolju u Beogradu samo je još više utjecala na širu promociju načela narodnog jedinstva i organiziranije poticanje južnoslavenskog pokreta u skladu s okolnostima tako da se on najviše izražavao na području promicanja kulturnih veza. Tijek vremena pokazao je da je u splitskom primjeru bila očita heterogenost navedene skupine političara koja se najviše izražavala u generacijskoj podjeli i međusobnim rivalitetima. Potonji problem bio je napose vidljiv u sukobima između dvojice splitskih odvjetnika, Ante Trumbića i Josipa Smodlake, oko provedbe političke taktike, no obojica su u suštini ostali dosljedni protivnici Dvojne Monarhije i zagovornici južnoslavenskog povezivanja kao ključa za prevladavanje dvostruke hegemonije pod habsburškom dinastijom. Upravo na tragu taktičkih razlika osnovana je pod Smodlakinim vodstvom Hrvatska pučka napredna stranka, koja je bezuvjetno zastupala ideologiju jugoslavenskog nacionalizma i u čijim su se redovima nalazila mlada, ali već renomirana i poduzetna imena poput Ivana Meštrovića, Ive Tartaglie, Emanuela Vidovića, Prvislava Grisogona i Vicka Iljadice bez čijeg bi udjela, naročito onog umjetničkog, agitacija tog relativno uskog, ali vrlo utjecajnog kruga bila znatno slabije prohodna. ${ }^{2}$ Taj liberalno-naprednjački krug bio je i nešto širi jer su „mnoge splitske porodice znatno ranije bile nadahnute srbofilskim jugoslavenstvom kao ideologijom", o čemu je svjedočio i dolazak srpskog prijestolonasljednika Aleksandra u kolovozu 1910. u Split kao i nadolazeći Balkanski ratovi u kojima su sudjelovali i splitski dobrovoljci. ${ }^{3} \mathrm{Na}$ početku Prvoga svjetskog rata dio dalmatinskih naprednjaka i jugoslavenskih simpatizera bio je pohapšen i interniran u raznim mjestima Austrije, dok se Meštrović s Trumbićem priključio zadaći osnivanja Jugoslavenskog odbora u inozemstvu. Unatoč brojnim sporovima između vodstva tog Odbora i predsjednika srbijanske vlade, tijekom rata njihov je zajednički cilj bio rušenje Monarhije i „narodno ujedinjenje“ stvaranjem jugoslavenske države što su usuglasili potpisivanjem Krfske deklaracije. Kraj rata pokazao je pak da povijesni razlozi vode prema trajnom raskidu $s$ bečkim centralizmom pod kojim se navedeni krug osjećao skučeno, a potreba za hitnom obranom od prijetnji ekspanzije talijanskog nacionalizma išla je u prilog nove zadaće koju su kroz svoje djelovanje kontinuirano zagovarali pripadnici političke emigracije od Sarajevskog atentata na dalje.

U takvom je ambijentu Split sa svojim vodećim ljudima doživio razdoblje epohalnog prevrata i pri tome postao jednim od snažnijih okupljališta zagovaratelja različitih tipova jugoslavenstva. ${ }^{4} \mathrm{Na}$ sastanku održanom 2. srpnja 1918. pristalice raznih stranaka iz Dalmaci-

2 Tihomir Cipex - Stjepan Matкović, Programatski dokumenti hrvatskih političkih stranaka i skupina 1842. - 1914., Zagreb 2006., 567-586; Norka Machiedo Mladinić, Životni put Ive Tartaglie, Split 2001., 25-46.

3 Anatolij Kudrjavcev, Ča je pusta Londra..., Split 2002., 61 i Frano IvanišEvić, Narodni preporod u Dalmaciji, Split 1932., 104.

4 O različitim tipovima jugoslavenstva vidi: Jovo BAKIĆ, „Nova Evropa: između prečanskog integralnog i hrvatskog minimalnog jugoslovenstva“, Nova Evropa 1920-1941. Zbornik radova (ur. Marko Nedić i Vesna Matović), Beograd 2010., 108-121. 
je osnovali su Narodnu organizaciju s političkim programom: ,jedinstveni narod Srba, Hrvata, Slovenaca ima neotudjivo pravo i dužnost da srestvom samoodredjenja ostvari svoju jedinstvenu nezavisnu državu." ${ }^{\text {"S }}$ Tom su prigodom ustrojeni politički i gospodarski odbori u čijim redovima će biti neki od najistaknutijih zagovornika jugoslavenske ideje u međuratnom razdoblju. Budući senator Majstrović tada je izrazio nezadovoljstvo što su u Banskoj Hrvatskoj do izražaja došle stranačke borbe tako da je Dalmacija bila „pozvana“ potaknuti proces jedinstvenog političkog djelovanja. Sljedeća činjenica bila je da su iz političkog kuta gledanja predstavnici dalmatinske Zemaljske vlade imali pri kraju studenoga 1918. jednu od važnijih uloga u postupku ubrzanog proglašavanja zajedničke države sa Srbijom jer su svojim prijedlogom koji su uputili Narodnom vijeću SHS u Zagrebu ultimativno zaprijetili da će se Dalmacija samostalno ujediniti sa Srbijom ako Narodno vijeće, kao vodeći faktor Države SHS, ne požuri pozitivno definirati svoj odnos sa službenim Beogradom i time stvoriti integralnu južnoslavensku državu. ${ }^{6}$ Ulazak savezničke vojske u Split i napeto iščekivanje rezultata Mirovne konferencije još su više poticali mišljenje među „integralistima“ da će se prihvaćanjem centralističkog uređenja Kraljevstva SHS ubrzati koheziju nove države i pokazati njezina unutarnja snaga. ${ }^{7} \mathrm{~S}$ druge strane, one političke snage koje su tijekom promjena sa svojim programima republikanizma i primjene načela narodnog samoodređenja stekle širu potporu ili održavale svoje od ranije izgrađene pozicije na području Banske Hrvatske još nisu imale čvršća uporišta u Dalmaciji i trebat će proći određeno vrijeme da zauzmu istaknutiji položaj u javnom životu. Shodno takvim odnosima moglo se očekivati da će nova državna tvorba imati svoje čvrsto uporište u dalmatinskom središtu. Osnivaju se ustanove poput Jugoslavenskog Lloyda, Jadranske straže i podružnice središnjeg odbora Jugoslavenske matice iz Beograda koje su nastojale kroz kulturno-socijalni i privredni rad, napose jačanje pomorske svijesti, poticati svijest o potrebi jačanja veza unutar Kraljevine i održavati utjecaj na iseljeništvo. ${ }^{8}$ Skora pojava Organizacije jugoslavenskih nacionalista sa centralnim odborom u Splitu, u koju zapravo i nisu bili uključeni mnogi jugoslavenski orijentirani pojedinci iz tog grada, bila je važna potvrda u prilog vidljivosti takvog tipa državnih integralista spremnih i na korištenje fizičke sile. ${ }^{9}$ Međutim, prvotni optimizam polako je kopnio i unutarnja državna kriza utjecat će na postupnu promjenu raspoloženja u prilog onih snaga koje su bile nezadovoljne beogradskom upravom. ${ }^{10}$ Kao jedan od pokazatelja

\footnotetext{
„Narodni zbor u Splitu. Politička rezolucija“, Novo doba (Split), br. 24, 3. 7. 1918., 1.

Zlatko Matijević, „Narodno vijeće Slovenaca, Hrvata i Srba u Zagrebu“, Fontes, 14/2008., 63.

7 Prema izvješćima američke mornarice ,jedan element jugoslavenskog naroda koji ne želi da Jugoslavija bude dio Srbije“, a ta je „stranka ovdje u manjini, ali su njezini članovi navodno iz redova intelektualaca i kulturnih viših klasa“. Vidi: Vjekoslav Perica, „Međunarodna misija u Splitu nakon Prvoga svjetskog rata“, Časopis za suvremenu povijest, 42/2010., br. 1, 148 .
}

8 Hrvatski državni arhiv, Građanske stranke i društva, grupa VII, br. 2163; Grga NovaK, Naše more, Zagreb 1932. , 285-326 i Norka Machiedo Mladinić, Jadranska straža, Zagreb 2005.

9 O Orjuni vidi: Branislav Gligorijević, „Organizacija jugoslovenskih nacionalista“, Istorija XX veka, knj. V, Beograd 1963., 315-396; Ivan J. Bošković, Orjuna. Ideologija i književnosti, Zagreb 2006. i Stevo Djuraskovic, Fascism in Central Europe: The Organisation of the Yugoslav Nationalists-Orjuna, 1921-1929, magistarski rad, Budimpešta 2007. Među pripadnicima Orjune nije bilo niti jednog budućeg senatora iz Splita. Prema navedenim autorima najbliža veza s jednim od budućih senatora bio je njegov brat Berislav Angjelinović.

10 I glasilo dalmatinskih radikala prije uvođenja diktature navodi: „Prvih godina po oslobogjenju i ujedinjenju o Dalmaciji i o njezinoj važnosti za cijelu našu Kraljevinu nije se vodilo onoliko brige, koliko je trebalo.“ Vidi: „Dalmacija nakon Kraljeva puta“, Država (Split), br. 163, Split, 10. 10. 1925., 1. 
širenja nezadovoljstva dovoljno govori činjenica da su i neki neosporni zagovornici stvaranja integralne jugoslavenske države i jugoslavenstva postali razočarani razvojem situacije te su se shodno tome ili vratili svojim ishodišnim političkim korijenima ili su se okrenuli kritici državnog centralizma. Ni neki drugi potezi poput onog da je Split nakon proglašenja šestosiječanjske diktature i donošenja Zakona o nazivu i podjeli Kraljevine Jugoslavije na upravna područja postao sjedištem Primorske banovine nisu više mogli potisnuti rašireno nezadovoljstvo stanjem u državi, napose stoga što ni mjere diktatorskog režima nisu pridonijele bržem suzbijanju posljedica gospodarske krize, a nacionalno se pitanje sve više zaoštravalo. $S$ druge je strane dio elite i dalje vjerovao u mogućnosti popravljanja odnosa u državi ili se nadao njezinoj konsolidaciji pri čemu su otpočetka smatrali da je raspuštanje Narodne skupštine i svih stranaka bilo opravdano zbog težine međustranačkih sukoba i da je zato bilo nužno „uvesti reda“" ${ }^{11}$

Ustav od 3. rujna 1931. uveo je dvodomno Narodno predstavništvo, koje se sastojalo od Narodne skupštine i Senata. Uvođenje takvog sustava doživjelo je podršku režimski orijentiranih skupina koje su tvrdile da je Senat „stvorio Kralj Ujedinitelj, rukovođen Svojom Karađorđevskom pronicljivošću i mudrošću, sa naročitim zadatkom da Senat bude budni čuvar velikih ideja Ujediniteljevog Manifesta od 6 januara 1929 godine, branilac jugoslovenske misli i zatočnik ustavnog poretka u zemlji “. ${ }^{12}$ Ustavni je zakon odredio da Senat ima mješovito obilježje prigodom njegova popunjavanja. Sastojao se od 46 izabranih i od kralja imenovanih senatora, pri čemu se izbor obavljao u tijelima banovina na ograničen način jer su pravo glasa imali narodni zastupnici u Narodnoj skupštini, svi banovinski vijećnici i svi prisjednici općina tako da je taj izbor ovisio o potpori režima. ${ }^{13} \mathrm{Bi}$ ranje senatora bilo je javno, obavljalo se prema biračkom popisu i održavalo po izbornim jedinicama na način da je svaka banovina predstavljala jednu izbornu jedinicu, a takav status imao je i Beograd sa svojim upravnim područjem kao središte države. Osim toga, Ustav je odredio da je starost od četrdeset godina uvjet za obavljanje senatorske dužnosti, a mandat senatora je trajao šest godina. Kasnije se često govorilo da su senatori bili isluženi političari koji su naročito u slučaju imenovanja bili zapravo časno umirovljeni. Međutim, popis senatora ukazuje da je među njima bio niz eminentnih imena iz različitih sfera djelovanja, čija je riječ i dalje imala svoj značaj u javnosti Kraljevine Jugoslavije. Na taj je

11 Veliki župan splitske oblasti je 25. 1. 1929. raspustio i „one stranke koje do sada nisu bile raspuštene a to su: organizacije Narodne Radikalne Stranke, Jugoslavenske Demokratske Stranke, Samostalno-Demokratske Stranke, Zemljoradničke Stranke i Ženski pokret“. „Daljnje raspuštanje stranačkih organizacija u Splitu“, Novo doba (Split), br. 25, 25. 1. 1929., 4.

12 „Živeli Senator!“, Jugoslovenski glas (Zagreb), br. 1, 7. 1. 1936., 2.

13 Dalibor Čepulo, Hrvatska pravna povijest u europskom kontekstu, Zagreb 2012., 274-275 i Ferdo Čulinović, Jugoslavija izmedu dva rata, knj. II, Zagreb 1961., str. 33-34. Tekst zakona o izboru senatora vidi u: Politika (Beograd), br. $8404,2.10 .1931 ., 1-2$. 
način Senat trebao biti elitističko okupljalište koje nadopunjuje rad Narodne skupštine i može korigirati njezino djelovanje.

Iz područja Splita i njegove okolice birano je ili imenovano više senatora. Na prvim izborima za Senat u Primorskoj banovini, koji su održani 3. siječnja 1932. u Splitu kao i u ostalim banovinskim središtima Kraljevine Jugoslavije, izabrani su ministar bez lisnice Nikola Precca te dvojica odvjetnika Uroš Desnica i Ivo Majstrović. Prema lokalnim izvješćima glasanje je obavljeno u vijećnici splitske općine. Od 143 registriranih glasača, izboru je pristupilo njih 118 ili 82\% uz objašnjenje da su loše vremenske prilike - velik snijeg u zaleđu i otežani promet - onemogućile bolji odaziv izbornika. ${ }^{14} \mathrm{Na}$ biralištima nisu bile prijavljene nepravilnosti niti je došlo do uobičajenih izgreda, kao što je to bio slučaj tijekom parlamentarnih izbora. Kao prvi izabrani zamjenik senatora Nikole Precce iz Hercegovine izabran je tom prigodom i don Petar Gjirlić. On je zbog Preccina zadržavanja skupštinskog mandata u mostarskom izbornom srezu ušao u Senat, gdje se pokazao kao jedan od aktivnijih senatora. Sljedeće godine, 18. lipnja, kraljevim je ukazom za senatora imenovan don Frano Ivanišević. Na dopunskim izborima od 3. veljače 1935. za novog je senatora izabran Budislav Grgur Angjelinović. Izbori održani 6. veljače 1938. za Primorsku banovinu uveli su u Senat kandidate koji nisu bili iz Splita. ${ }^{15}$ Konačno, posljednji izbori uslijedili su 12. studenoga 1939. u znatno izmijenjenim okolnostima jer je u međuvremenu ustrojena Banovina Hrvatska, kojom su nestale Savska i Primorska banovina, tako da su izbori za novo jedinstveno područje održani u zagrebačkoj Gradskoj vijećnici. ${ }^{16} \mathrm{Na}$ tim su izborima postavljene liste vladajućih skupina u ime Jugoslavenske radikalne zajednice i Hrvatske seljačke stranke u savezništvu sa Samostalnom demokratskom strankom, dok su se oporbene stranke sustegnule od glasanja. I tom prigodom nije više bilo izabranih senatora iz Splita. ${ }^{17}$ Ipak, među senatorima su formalno bila još tri dobro poznata imena iz splitskog miljea. Kraljevski namjesnici su 16. rujna 1939. ukazom imenovali za senatore liječnika Jakšu Račića, bivšeg gradskog načelnika i bana Ivu Tartagliu te bivšeg poslanika Josipa Smodlaku. ${ }^{18}$ Međutim, oni više nisu ni mogli sudjelovati u radu Senata jer se on više nije sastajao, a u obzir valja uzeti i činjenicu da su vlasti Banovine Hrvatske zagovarale parlamentarnu apstinenciju jer su smatrale da su dotadašnji izbori bili nelegitimni. Na kraju, formalno bi među splitske senatore mogao biti uvršten i Lujo Vojnović, ako bi se u obzir uzela činjenica da se rodio (1864.) u Splitu. No, iz njegovih je nastupa, koji su u mnogo čemu bili podudarni s

14 „Izbor senatora za Primorsku Banovinu“, Novo doba (Split), br. 2, 4. 1. 1932., 1.

15 U Primorskoj banovini izabrani su nositelj liste HSS-a zemljoradnik Šime Belamarić iz Mandalice kod Šibenika i nositelj liste Jugoslavenske radikalne zajednice nadzornik škola u mirovini i predsjednik općine u Kninu Dušan Novaković, dok su njihovi zamjenici bili gostioničar Ilija Škobić iz Konjica i posjednik Danilo Desnica iz Obrovca. Izborima je pristupilo 130 od 159 birača s pravom glasa, pri čemu je HSS dobio 69, a JRZ 61 glas. Vidi: „Juče su izvršeni izbori za Senat“, Politika (Beograd), br. 10669, 7. 2. 1938., 3.

16 Prigovore zbog raspisivanja senatskih izbora u ime „opozicionoga jugoslovenskog mišljenja u banovini Hrvatskoj“ u skladu sa tumačenjima zakonskih odredbi vidi u: „Pred senatske izbore“, Narodni list (Split), br. 2, Split, 9.11. 1939., 1.

17 S dalmatinskog područja bivše Primorske banovine izabrani su bivši načelnik Dubrovnika Miho Skvrce, seljak Nikola Srdović, seljački posjednik Šime Belamarić, bivši ministar Niko Subotić iz Šibenika i predsjednik općine Korčule Vinko Sarnečić. Na te se izbore odazvalo „oko 400“ od ukupno 785 upisanih birača. Vidi: „Juče je izvršen izbor 47 senatora“, Politika (Beograd), br. 11298, 13. 11. 1939., 4.

18 Vidi: „Ukazom kraljevskih namesnika imenovano je 37 senatora“, Politika (Beograd), br. 11302, 17. 11. 1939., 5. 


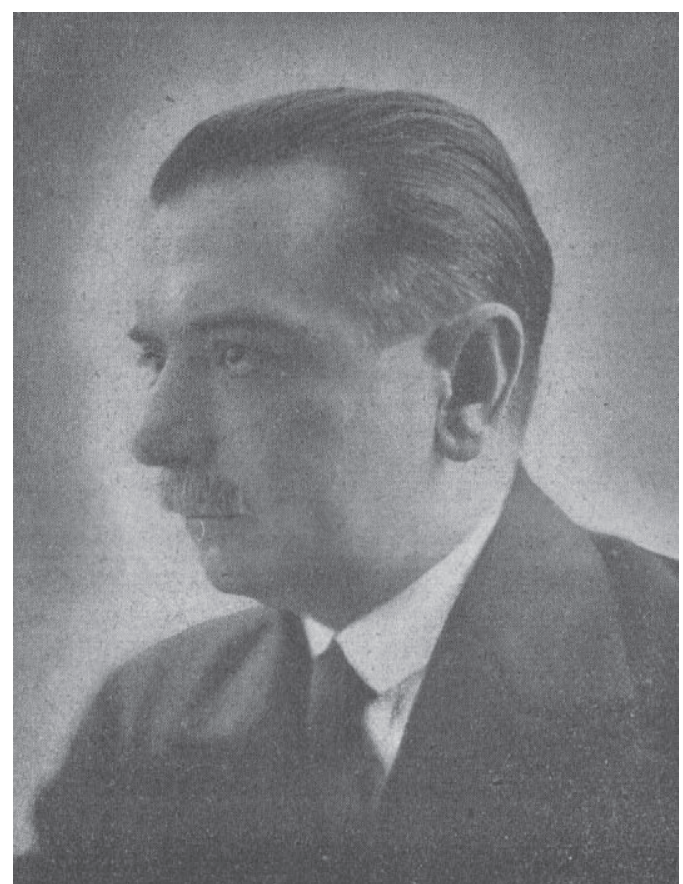

Sl. 1. Ivo Tartaglia, gradonačelnik Splita 1918. - 1928.

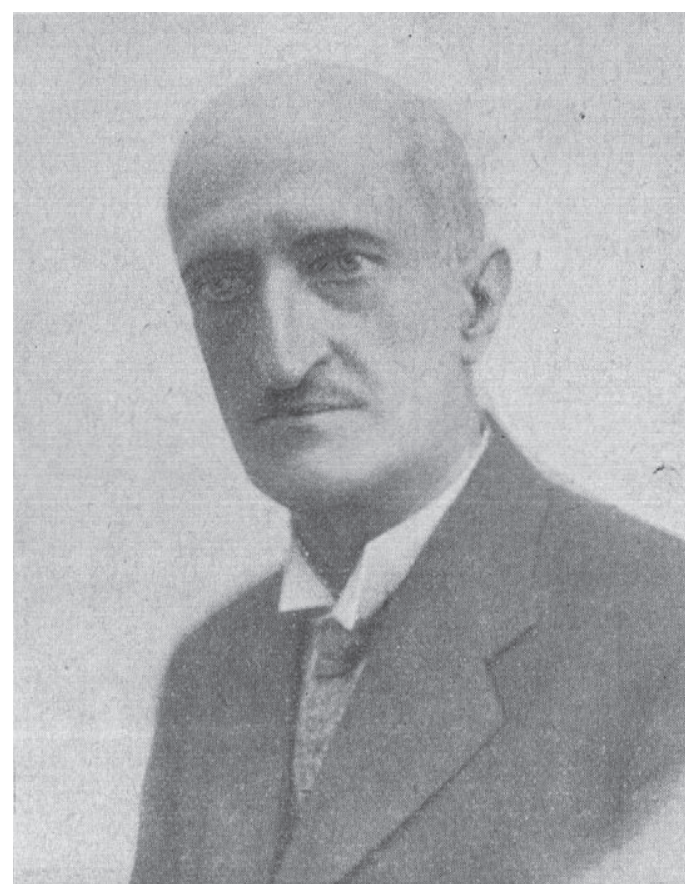

Sl. 2. Jakša Račić, gradonačelnik Splita 1929. - 1933.

drugim senatorima koji su opravdavali kraljevu politiku od 6. siječnja 1929. i jugoslavenski integralistički pravac, vidljivo da nije imao dodirnih točaka sa svojim rodnim gradom, nego je u središte zanimanja kad je riječ o lokalnim prilikama ponajprije stavljao Dubrovnik, koji je bio po mnogim pojedinostima povezan s poviješću poznate obitelji Vojnović.

\section{KRATKE BIOGRAFIJE SENATORA}

Ukažimo sada abecednim redom na biografske podatke o aktivnim senatorima koji su dolazili iz Splita i okolice. Budislav Grga Angjelinović bio je rodom (1886.) iz Sućuraja na otoku Hvaru. Gimnaziju je završio u Splitu. Pohađao je studij prava u Zagrebu, Pragu i Lavovu, doktorirao je u Zagrebu i Lavovu, a diplomirao još studij povijesti i zemljopisa u Zagrebu. Tijekom studija bio je jedan od prvaka Starčevićanske akademske mladosti koja je pristajala uz frankovačke pravaše, iz čega se moglo pretpostaviti da će se razviti u nacionalnog radikala. Pri kraju studija sudjelovao je u pokretanju omladinske revije Mlada Hrvatska (1908.) i predvodio mladohrvatski pokret, koji je ubrzo napustio odlaskom u Dalmaciju, gdje je započeo karijeru kao odvjetnički pripravnik u Zadru i Splitu. Politički se vezao uz dalmatinsku Stranku prava u kojoj se isticao po protuaustrijskim nastupima, distancirajući se time u potpunosti od frankovačke ideologije strogo vezane uz rješavanje hrvatskog nacionalnog pitanja unutar habsburškog okvira. Za vrijeme Prvoga svjetskog rata više je puta kao politički nepouzdana osoba uhićen i interniran u Šibeniku, Zadru, Mariboru i 
Grazu. Nakon amnestije koju je proveo novi car i kralj Karlo I. (IV.) prešao je u Zagreb, gdje je suuređivao utjecajni dnevnik Hrvatska država. Riječ je o organu Starčevićeve stranke prava (SSP), koja je preuzela jednu od glavnih uloga u koncentraciji različitih stranaka i struja okupljenih oko jugoslavenskog pokreta. Nakon smrti njezinog predsjednika Mile Starčevića i dolaska na taj položaj zubara Ante Pavelića, još jednog jugoslavenskog senatora u budućnosti, SSP je nastavila zastupati antantofilski smjer s time da je postupno zauzimala sve otvoreniji stav protiv opstojnosti AustroUgarske i habsburške dinastije te se zalagala za provedbu jugoslavenske državotvorne ideje. Angjelinović je nakon uspostave Narodnog vijeća SHS pri kraju 1918. postavljen za njegova tajnika, člana plenuma, povjerenika Sekcije za organizaciju i agitaciju te povjerenika za javnu sigurnost u Zagrebu. Na tom je položaju

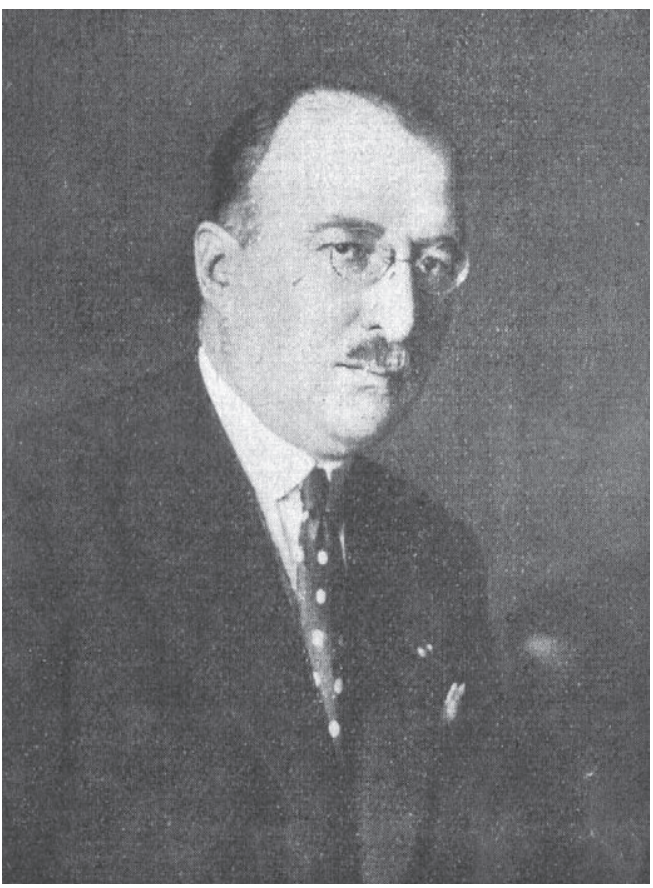

Sl. 3. Budislav Grga Angjelinović proveo gušenje pobune 53. i 25. domobranskih pukovnija iz sastava tada već poražene i propale zajedničke austro-ugarske vojske na Jelačićevom trgu. Kasnije je polemizirao u međuratnom tisku o tom krvavom događaju, braneći svoje odrješito držanje u obračunu s protivnicima kao jedini način obrane ujedinjenja. Najpoznatiji je bio njegov proturječni istup na sjednici Ustavotvorne skupštine kada je obraćajući se zastupnicima u povodu javnih prozivanja neuvijeno izjavio: „Gospodo onda sam ja po mojoj dužnosti smatrao da treba prvi tako da počnem, smatrao sam da je to moja dužnost i ja se s tim krvavim rukama, koje mi prebacuju, ponosim. “19 Premda je svoja gledišta prilagođavao političkim promjena, ostao je dosljedan samoobrani te povijesne epizode pa je i u Senatu izjavio 1939. da je „vazda bio nosilac čvrste ruke prema frankovcima, koji hoće da ruše državu“. Narodno vijeće SHS izabralo ga je u Privremeno narodno predstavništvo, a u Ustavotvornoj skupštini je glasovao za prihvaćanje Vidovdanskog ustava. Uspostavom Kraljevstva SHS pristupio je Demokratskoj stranci (DS), znatno pridonijevši širenju njezinih organizacija po Dalmaciji koje su zagovarale primjenu načela integralnog jugoslavenstva. No, izrazio je neslaganje prema represivnom dijelu metoda ministra unutarnjih poslova Svetozara Pribićevića, koji je uskoro osnovao Samostalnu demokratsku stranku i tako postao velikim suparnikom u osvajanju „prečanskog“ političkog prostora. S druge strane, njegova braća, odvjetnici Beri-

19 „Jedinstvo, federalizam, autonomizam'. Govor dra B. G. Angjelinovića na sjednici Ustavotvorne skupštine 26. IV 1921.“, Riječ (Zagreb), br. 98, 30. 5. 1921., 6. 
slav i Danko, koji je bio i književnik, bili su također istaknuti u javnom životu kao pristaše jugoslavenske nacionalističke ideje. ${ }^{20}$

Poput većine budućih senatora i Angjelinović je zauzimao izrazito kritičan stav prema radićevskoj politici, smatrajući je simbolom nenačelnih metamorfoza. Tako je osobito kritizirao ulazak Radića i HSS-a u vladu s radikalima kao štetan potez za načela jugoslavenstva. ${ }^{21}$ Angjelinović je u svojoj stranci bio član glavnog odbora, a 1928. je izabran za predsjednika posebne organizacije hrvatskih demokrata u sklopu DS-a. Podržavao je stranački program održivosti političkog sustava na Vidovdanskom ustavu i zagovarao poboljšanje hrvatsko-srpskih odnosa, koji su bili ključ jugoslavenske politike. Kao pripadnik DS-a biran je u Narodnu skupštini na svim izborima od 1920. do 1927., a u kabinetu prve vlade Velje Vukićevića (1927. - 1928.) imenovan je ministrom pripreme za Ustavotvornu skupštinu i izjednačenje zakona. U tom je razdoblju zauzeo stanovište da su Hrvati, Srbi i Slovenci jedan narod, uvjeren je da će se tradicionalna „plemena“ stopiti u jugoslavenstvu te se istodobno isticao kao jedan od ustrajnih protivnika učestalih prijedloga o potrebi federativnog uređenja države. Za njega je Beograd morao biti središte državne politike jer on nije više srpski, nego jugoslavenski glavni grad. U tom je smislu zahtijevao stvaranje jedinstvenog fronta koji treba voditi beskompromisnu borbu protiv protivnika narodnog jedinstva bez obzira na njihova ideološka usmjerenja. Na oblasnim izborima 1927. njegova je lista ostvarila zapažen rezultat u južno-dalmatinskom izbornom okrugu. Nakon atentata na Stjepana Radića i drugove u Narodnoj skupštini predsjednik vlade Anton Korošec imenovao ga je ministrom građevina. Prigodom dolaska u Split (5. 9. 1928.) priređene su demonstracije protiv njegova političkog držanja. One su ukazale da je skupštinsko krvoproliće u znatnoj mjeri utjecalo na promjenu klime u tom gradu. Nakon uvođenja šestosiječanjske diktature Angjelinović je postao jednim od oslonaca režima iz redova hrvatskog kadra. Na početku 1929. imenovan je opunomoćenim ministrom i izvanrednim poslanikom u Pragu, a kasnije i poslanikom u Beču. Izabran je ponovno za narodnog zastupnika na skupštinskim izborima 1931. i 1935., a zatim je sudjelovao u osnivanju režimske Jugoslavenske nacionalne stranke (JNS), u kojoj je obavljao dužnost drugog potpredsjednika i stranačkog predsjednika banovinskog odbora Primorske banovine. Na toj se dužnosti zalagao za stvaranje jugoslavenskog duha koji je, po njemu, trebao biti podloga funkcioniranja države. ${ }^{22} \mathrm{U}$ vladama Milana Srškića i Nikole Uzunovića nastavio je obavljati ministarske dužnosti tako da je kod prvoga bio ministar bez portfelja (1932. - 1934.), a kod drugoga i ministar za fizički odgoj. Na dopunskim izborima 3. veljače 1935. izabran je za senatora u Primorskoj

$\overline{20}$ O ulozi Berislava Angjelinovića u Orjuni vidi: B. GLigorijević, „Organizacija jugoslovenskih nacionalista“, 326327. Upada u oči da će kasnije Ivo Tartaglia opisati senatora B. G. Angjelinovića isto tako kao „orjunaša“ koji je ekstremnim potezima pokušavao fašizirati Jugoslaviju. Aleksandar JAKIR - Norka MaCHIEdo-Mladinić (ur.), Izabrani spisi Ive Tartaglie, Split 2013., 323.

21 Tonći Šitin, „Prodor i pobjeda HSS-a u Dalmaciji (1923.-1928.)“, Radovi Zavoda za hrvatsku povijest, 32-33/1999. $-2000 ., 313$.

22 „Prva skupština stranke“, Pučka prosvjeta, 12/1932., br. 11, 242. Vrsni novinar i neko vrijeme jugoslavenski diplomat Bogdan Radica nepovoljno je zbog odnosa prema središtu Kraljevine ocijenio Angjelinovića i još neke Dalmatince parafrazirajući Trumbića: „(...) služeći Beogradu, uspavljaju Beograd i zavaravaju ga.“ Bogdan RAdicA, Živjeti nedoživjeti, knj. 2, München - Barcelona 1984., 11. 
banovini kao jedini kandidat $s$ istaknutom listom. Ipak, na posljednjim skupštinskim izborima 1938. ostvario je slab rezultat u splitskom izbornom kotaru čime se pokazalo da je njegova karijera koja se tada kretala u okvirima „blage opozicije“ zadobila padajuću putanju. Međutim, on je i dalje obavljao dužnosti poput direktora novopokrenutog Narodnog lista, tjednika JNS-a za primorske krajeve u Splitu, kojim se nastojalo okupiti jugoslavenske elemente u sklopu Banovine Hrvatske i održati ih na javnoj sceni. Pri tome je zamjetno da je vrlo glasnu oporbu od tada imao među pristašama lokalnih sokolskih društava, koji su smatrali da je Angjelinović revidirao ideju jugoslavenskog nacionalizma jer je započeo prozivati srbijanske političare da su zloupotrijebili centralnu vlast u svoju korist i tvrditi da je nastupilo razdoblje kad je nužno rješavanje hrvatskog pitanja unutar Kraljevine Jugoslavije. U Senatu je 1938. izabran u Odbor za proučavanje međunarodnih konvencija. Istovremeno je dosljedno kritizirao vanjsku politiku predsjednika vlade Milana Stojadinovića zbog zatopljavanja odnosa s nacističkom Njemačkom i fašističkom Italijom jer je u tome vidio samo još jedan prilog urušavanju ustanova dotadašnje kolektivne sigurnosti u Europi. Tijekom 1939. u Senatu je kao - kako se sam predstavio - ,jugoslavenski nacionalist hrvatskog plemena" lojalan kruni načelno podržao sporazum predsjednika vlade s Hrvatskom seljačkom strankom, uz zadržavanje opozicijskog stava prema Cvetkoviću i Mačeku, smatrajući da se samo „saradnjom svih plemena ili dijelova naroda stvara ili izgradjuje jugoslovenska misao i jugoslovenski narod u jugoslovenskoj državi“. Neposredno nakon sloma Kraljevine Jugoslavije u travnju 1941. otišao je u emigraciju, gdje je obavljao dužnost ministra u izbjegličkoj vladi. Održao je niz propagandnih govora na londonskom radiju, zagovarajući stvaranje jedinstvenog fronta u borbi protiv njemačkih okupatora. Agitirao je dosta među iseljenicima u Južnoj i Sjevernoj Americi. Pri kraju rata (1944.) se u pismu upućenom predsjedniku izbjegličke vlade Božidaru Puriću ogradio od rada kraljevske vlade, a nakon svršetka rata vratio se u domovinu i izražavao oporbena gledišta prema novim vlastima.

Uroš Desnica (rođ. 1874.) je bio rodom iz Obrovca i dolazio je iz već etablirane obitelji u javnom životu. Osnovnu školu završio je u rodnom mjestu, a u Zadru je maturirao u klasičnoj gimnaziji. Zatim je studirao pravo u Beču, gdje je u osvit 20. stoljeća stekao i doktorat (1900.). U središtu Monarhije se tijekom studija istaknuo kao jedan od agilnijih sudionika udruge srpskih studenta Zora. Nakon završetka studija vratio se u Zadar i otvorio vlastiti odvjetnički ured. Politički se aktivirao u sklopu već uhodane Srpske stranke za Primorje, koja je djelovala na području Dalmacije i svoju izbornu bazu imala na području zadarskog zaleđa i u Boki kotorskoj. Desnica je bio među potpisnicima značajne Zadarske rezolucije (1905.), koju su sastavili predstavnici srpskih stranaka iz Banske Hrvatske i Dalmacije, čime je politika „novoga kursa“ kroz širu suradnju hrvatskih i srpskih političara te nagovještaj mirnijeg suodnosa is talijanskim političkim predstavnicima doživjela klimaks. ${ }^{23} \mathrm{Uz}$ to

23 U biografskoj natuknici o njemu, koju je napisao sveučilišni profesor iz Beograda Dragoslav Pavlović, a objavljena je u Hrvatskoj enciklopediji (sv. 4, Zagreb 1942., 687) Uroš Desnica opisan je kao jedan od prvaka „među Srbima u Dalmaciji“ koji je „vodio živu borbu protiv talijanske okupacije Dalmacije“. Podatak je znakovit u kontekstu vremena i mjesta objavljivanja te natuknice jer prema podatku iz impresuma tada još nije došlo do talijanske kapitulacije u Drugome svjetskom ratu i novonastale geopolitičke situacije u kojoj Italija više nije bila saveznik NDH. Međutim, prema svemu sudeći taj je svezak objavljen u ljeto 1943. tijekom Mussolinijeva pada. O leksikografskoj obradi obitelji 
je bio izabran u „odbor za sporazum radi zajedničke akcije s Hrvatima“ u svojstvu zamjenika Antuna Puljezija. S gledišta svjetonazorskih podjela ubrajan je među srpske političare mlađe liberalne orijentacije koji su postupno potiskivali konzervativnu struju predvođenu višim pravoslavnim svećenstvom i tako preuzeli glavnu ulogu u Srpskoj stranci. ${ }^{24} \mathrm{U}$ povodu proglašene i izvedene aneksije Bosne i Hercegovine Desnica je objavio protuaustrijske članke u talijanskim časopisima, čime se svrstao u krug političara koji su otvoreno osudili državno priključenje dvaju nekadašnjih pokrajina osmanske imperije, vidjevši u njemu jedan od pokazatelja provedbe germanskog koncepta Drang nach Osten u djelo. Prije izbijanja rata bio je izabran u studenome 1913. za predsjednika Odvjetničke komore u Zadru, u kojoj su Hrvati i Srbi međusobnom suradnjom nadvladali talijansku dominaciju. ${ }^{25} \mathrm{Na}$ početku Prvoga svjetskog rata živio je na obiteljskom imanju u Islamu Grčkom, a od polovice posljednje ratne godine uključio se poput mnogih drugih političara u javni život. U članku „Srpski glas“, koji je objavljen u splitskom Novom dobu 12. lipnja 1918., zabilježio je da je rat izazvao „preobraženje“ u korist prihvaćanja jugoslavenske ideje kod Srba, Hrvata i Slovenaca. Time se uvrstio u pretežiti dio političara koji su nakon donošenja Svibanjske deklaracije u bečkom Carevinskom vijeću (30. svibnja 1917.) organizirano krenuli u rušenje dualističkog uređenja Monarhije uz polazišno načelo da su Slovenci, Hrvati i Srbi pripadnici jednog naroda i da je shodno tomu sljedeći korak stvaranje jugoslavenske države. Naravno, u vremenu donošenja Svibanjske deklaracije nije se još znalo kakav će biti ishod rata, no postavljeno načelo vodilo je time prema zagovaranju stvaranja jugoslavenske države u Monarhiji, a šire rješavanje u slučaju sloma Središnjih sila i diplomatskih okolnosti i izvan državnopravnih veza s habsburškom dinastijom. S raspadom Austro-Ugarske Desnica je imenovan potpredsjednikom i povjerenikom za pravosuđe u Zemaljskoj vladi Dalmacije te voditeljem njezina ureda. U Zadru je izdavao novine Naš list, koje nastaju nakon prisilnog gašenja etabliranog Narodnog lista, a biran je i za potpredsjednika Jugoslavenske čitaonice u Zadru, osnovane krajem studenoga 1918. spajanjem Hrvatske i Srpske čitaonice, koje su do tada zasebno djelovale. ${ }^{26} \mathrm{U}$ skladu s tim odrednicama oštro je istupao protiv talijanskog zauzeća znatnih dijelova Dalmacije. Desnica je za vrijeme talijanskog vojnog zaposjedanja Zadra bio uhapšen i interniran. Sudjelovao je u sastavljanju Apela naroda sjeverne Dalmacije (1919.) u kojemu se od Antante tražio prekid talijanske vojne okupacije. Vodio je odvjetnički ured u Obrovcu i politički se svrstao među pokretače Narodne radikalne stranke

Desnica više vidi u: Vladan Jovanović, „Članovi porodice Desnica u jugoslovenskim enciklopedijama i leksikonima“, Dijalog povjesničara - istoričara, knj. 9 (ur. Hans-Georg Fleck i Igor Graovac), Zagreb 2005., 243-257.

24 Takvu ideološku razdjelbu na liberalnu i konzervativnu struju, ne spominjući U. Desnicu, donosi Ante BraLić u: „Zadarski fin de siècle - političke i društvene prilike u Zadru i Dalmaciji uoči Prvoga svjetskog rata, Časopis za suvremenu povijest, 39/2007., br. 3, 739. U tom radu se ističe vodeća uloga Srba katolika u liberalnoj skupini kojom se ukazuje na problem viševjerskog odnosa u sklopu srpskog korpusa.

25 Josip Beroš, „Zadarska advokatska komora u narodnim rukama“, Odvjetnik, 33/1968., br. 9, 285. Zanimljivo je da je za potpredsjednika Komore istovremeno bio izabran Miho Skvrce, tada član Prodanove Stranke prava, a kasnije također senator iz Dubrovnika koji je dolazio iz redova Hrvatske seljačke stranke.

26 Jakša Ravlić (ur.), Zadar: Geografija, ekonomija, saobraćaj povijest, kultura, Zagreb 1964., 310 i 475. U vezi s Desničinim položajem u Zemaljskoj vladi, Smodlaka je tvrdio da je Desnica naknadno imenovan za Povjerenika za pravosuđe i to nakon talijanskog zauzimanja Zadra, kad je „pribjeglo u Split nekoliko pravoslavnih Srba“. S obzirom da u prvom sastavu Zemaljske vlade nije bilo Srba došlo je do prigovora srpskih izbjeglica iz sjeverne Dalmacije koji su onda bili usvojeni. Vidi: Josip Smodlaka, Zapisi dra Josipa Smodlake (ur. Marko Kostrenčić), Zagreb 1972., 58. 
u sjevernoj Dalmaciji, čiji je prvak prvo postao u benkovačkom kotaru. ${ }^{27} \mathrm{U}$ anketi o srpsko-hrvatskim odnosima iz 1922. krivce za napete odnose (,podvojenost“) između dvaju najbrojnijih naroda države vidio je na hrvatskoj strani, koja je prema njegovu mišljenju otpočetka imala zazor prema načinu ujedinjavanja, predlažući njezinu izolaciju i jedinstvenost „srpskog plemena“ kojim se treba očuvati njegov etnički prostor. ${ }^{28}$

Sljedeće godine izabran je za stranačkog predsjednika sjeverne i srednje Dalmacije te je uz Nikolu Subotića, budućeg ministra i isto tako senatora, imao ključnu riječ u promicanju radikalskog programa koji je na državnoj razini slijedio politiku predsjednika vlade Nikole Pašića, odbacivao republikanski pokret i branio ustavnu monarhiju. ${ }^{29}$ Međutim, neke pojave, poput nepovoljne konverzije novčanica austrijskih kruna u dinare na području okupacijske zone u sjevernoj Dalmaciji koja je išla

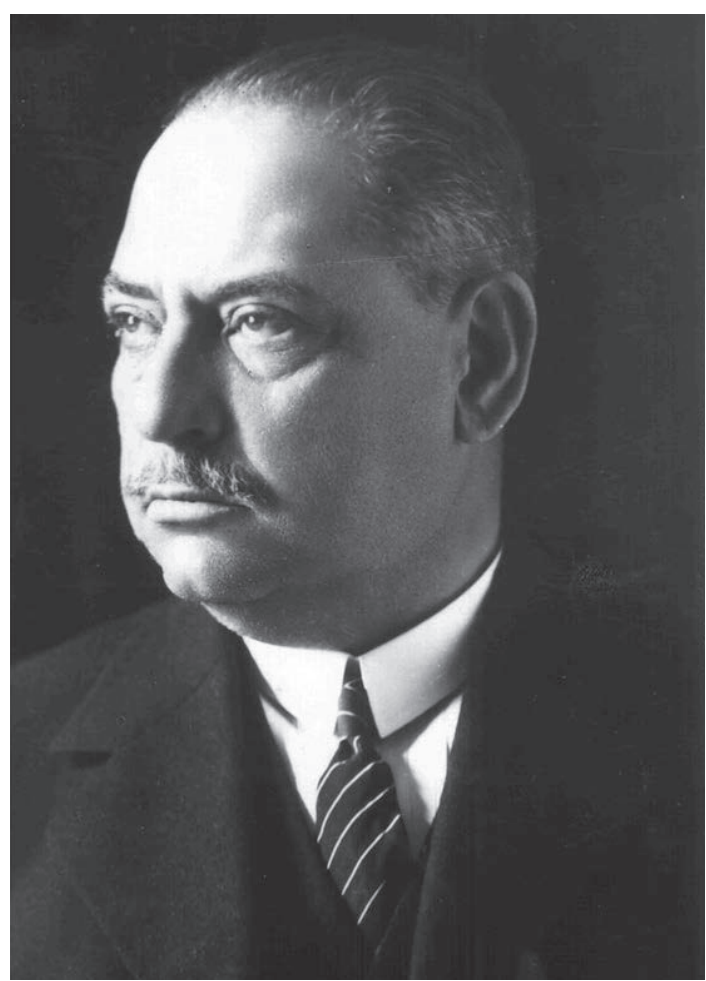

Sl. 4. Uroš Desnica na štetu lokalnog stanovništva, nisu ostale bez njegove kritičke analize na račun situacije u državi. ${ }^{30}$ Desnica je biran za narodnog zastupnika na skupštinskim izborima 1923. i 1925. u izbornom okrugu u Šibeniku za sjevernu Dalmaciju - kotar Benkovac. ${ }^{31}$ Prebacio je 1927. odvjetnički ured u Split, gdje je postao članom Advokatske komore te predsjednikom mjesne organizacije Narodne radikalne stranke. ${ }^{32}$ Sve do šestosiječanjske promjene vrlo je aktivno sudjelovao u promicanju svoje stranke na raznim zborovima u Dalmaciji i izvan svoje izborne baze (Sinj, Imotski, Dubrovnik, Pag i dr.), gdje se morao suočavati s

27 I neki drugi senatori s drugih područja Dalmacije pripadali su nakon 1918. radikalima, poput odvjetnika Melka Čingrije u Dubrovniku i Nikole Subotića u Šibeniku. Više o sastavu radikala u Dalmaciji: Gordana KrivokapićJović, Oklop bez viteza. O socijalnim osnovama i organizacionoj strukturi Narodne radikalne stranke u Kraljevini Srba, Hrvata i Slovenaca (1918 - 1929), Beograd 2002., 284-298. „Anketa o Srpsko-Hrvatskim Odnosima“, Srpski književni glasnik, knj. VI, br. 2, Beograd 1922., 118-119.

29 Desnica je svoju privrženost Pašićevoj politici pokazao i članstvom u Glavnom odboru za podizanje spomenika pokojnom Nikoli Pašiću. Usp. Država (Split), br. 288, 16. 3. 1927., 1.

30 Uroš DesniCA, „Nekoliko pitanja povodom izmjene novčanica u III zoni“, Dalmatinski radikal (Šibenik), br. 122, 19. 9. 1922., 1-2.

31 Dalmatinski glasnik (Split), br. 27, 4. 4. 1923., 1. Na parlamentarnim izborima 1923. Radikalna stranka dobila je najveći broj glasova u izbornom okrugu Šibenika. Iste godine glavni organ stranke Dalmatinski radikal premjestio je sjedište iz Šibenika u Split.

32 Prema stručnom časopisu Odvjetnik, koji donosi popis funkcionera odvjetničkih komora u Jugoslaviji, Desnica je bio potpredsjednik Advokatske komore u Splitu i član njezinog Disciplinskog vijeća. U toj komori su od senatora još bili zastupljeni dvojica Dubrovčana - Miće Mičić i Melko Čingrija. Usp. Odvjetnik, 4/1930., br. 5, 27. O Desničinom položaju u Narodnoj radikalnoj stranci: Država (Split), br. 311, 27. 7. 1927., 3. O njegovu stalnom nastanjenu u Splitu: Država (Split), br. 334, 19. 10. 1927., 3. 
radićevcima i pokušavati provesti programsku točku svoje stranke da ona oko sebe okuplja „sva tri plemena i sve tri vjere“. Poput mnogih drugih odvjetnika svoj materijalni status poboljšao je uključivanjem u poslovni svijet, o čemu svjedoči njegovo imenovanje za člana Upravnog odbora Portland cementa d. d. u Splitu. Taj podatak nije neobičan jer su i drugi senatori često pripadali ili bili uključeni u važnije poslovne krugove zbog čega su ponekad bili i predmetom javne rasprave. Desnica je bio biran i za člana Oblasne skupštine u Splitskoj oblasti kao predstavnik u njoj manjinske Narodne radikalne stranke u čije ime je više puta nastupao, a nakon uvođenja šestosiječanjskog režima imenovan je za člana Vrhovnog zakonodavnog savjeta. Predsjedao je do 1933. s Nikolom Subotićem Privrednokulturnom maticom za Sjevernu Dalmaciju, koja je 1929. baštinila imetak Okružnog odbora Narodne radikalne stranke iz Splita jer su sve političke organizacije nakon uvođenja šestosiječanjskog režima morale obustaviti svoj rad. Poslije je prvo podržao Jugoslavensku radikalno seljačku demokratiju, a zatim se vezao uz Jugoslavensku nacionalnu stranku na području sjeverne Dalmacije. ${ }^{33} \mathrm{U}$ tom je razdoblju objavljivao svoja gledišta u splitskom tjedniku Narodni list, organu te stranke u primorskom dijelu Hrvatske. ${ }^{34}$ Najviše se bavio pitanjima agrarnih odnosa, statusom seljaštva i sudstvom u srednjoj i sjevernoj Dalmaciji, razvojem radikalne ideologije, srpsko-hrvatskim odnosima i jugoslavenstvom. S obzirom da je redovito pisao u različitoj periodici od početka međuratne Jugoslavije, može se uočiti da su te teme bile predmetom njegova kontinuiranog zanimanja. ${ }^{35}$ Objavu sporazuma Cvetković - Maček popratio je kao i većina jugoslavenski orijentiranih političara iz Splita u nadi da će se time umiriti unutardržavne napetosti. Njegovo ime spomenuto je prigodom rasprave o akciji društva Krajina pod vodstvom senatora Petra Zeca. U njoj se tražilo da se Knin izdvoji iz sastava Banovine Hrvatske i pripoji Vrbaskoj banovini, pri čemu je dnevnik HSS-a Hrvatski dnevnik od 17. siječnja 1940. (br. 1333) istaknuo da Desnica kao istaknuti Srbin iz Dalmacije nije podržao takav zahtjev. Nakon kapitulacije Kraljevine Jugoslavije suorganizirao je rad Odbora za pomoć srpskim izbjeglicama u Dalmaciji, a umro je polovicom srpnja 1941. godine.

Svećenik Petar Gjirlić (rođ. 1886.), rodom iz Radošića, bio je do Prvoga svjetskog rata blizak pravaškim idejama. Nakon rata prvo je djelovao u sklopu Hrvatske pučke stranke u Dalmaciji, a zatim se približio radićevskom pokretu i postupno se uzdizao u hijerarhiji Hrvatske republikanske seljačke stranke do položaja stranačkog povjerenika u splitsko-šibenskom području i člana Pokrajinskog odbora stranke za Dalmaciju. Taj uspon pratio je probijanje radićevske stranke iz sjeverne Hrvatske u njezine južne dijelove, koje je nakratko zaustavljeno ulaskom HSS-a u kraljevsku vladu i napuštanjem republikanskog programa.

33 O tim političkim organizacijama više u: Milica BoDrožıć, „Obrazovanje Jugoslovenske radikalno-seljačke stranke“, Istorijski glasnik, br. 2-3, Beograd 1964., 39-95 i Momčilo PAvlović (prir.), Istorija gradanskih stranaka u Jugoslaviji 1918-1945. Tom 1, Beograd 2008., 352-360.

34 Prema službenim podacima banskih vlasti taj je tjednik, osnovan 1939., izlazio u nakladi od 2000 primjeraka.

35 Prema katalogu Leksikografskog zavoda Miroslav Krleža i dopunskih izvora Desničini članci se nalaze u sljedećoj periodici: Naša zemlja (1922.), Dalmatinski radikal (1922.), Država (1924. - 1938.), Radikalski glasnik (1924., 1927.), Mjesečnik. Glasilo Pravničkog društva (1931.), Narodni list (1920., 1940.), Novi list (1921.), Novi život (1921. - 1922.), Novo doba (1918.), Politika (1932. - 1933.), Srpski književni glasnik (1922.), Vreme (1928.), Magazin Sjeverne Dalmacije (1934. - 1935.). 
Od 1926. Gjirlić se priključio disidentima Hrvatske seljačke stranke i započeo napadati stranački vrh zbog političke nenačelnosti i zadovoljavanja privatnih interesa, zbog čega je bio isključen iz stranke. ${ }^{36}$ Kandidirao se na siječanjskim izborima za Oblasnu skupštinu (1927.) u Splitskoj oblasti. Tom prigodom bio je jedan od potpisnika predizbornog proglasa „Poruka Hrvatskom seljačkom narodu“. U njemu je zahtijevana revizija ustava, amnestija osuđenih i abolicija optuženih političara, rješenje agrarnog pitanja i izjednačenje poreza. Predvodio je pokretanje Hrvatskog seljačko-radničkog bloka, u kojem je surađivao s komunistima i istodobno nastavio $s$ kritikom radićevske politike. ${ }^{37}$ Taj neobični savez izazivao je različite reakcije. S jedne strane ukazivao je na propitivanje mogućnosti suradnje između krajnje ljevice i bivših radićevaca kao predstavnika radništva i seljaštva, ali je prema nekim komentarima bacao sumnju da su upravo vladajući radikali stajali iza te kombinacije koja je trebala oslabiti položaj HSS-a. Međutim, pokušaj osvajanja političkog prostora na račun premoćne radićevske stranke nije urodio većim uspjehom, izuzevši osvajanje jednog mandata na oblasnim izborima u Splitu. Dio literature ocjenjuje Gjirlića u kontekstu šestosiječanjske diktature „čovjekom povjerenja generala Živkovića“. Dopunu toj tvrdnji donosi podatak da je Gjirlić u Senatu pripadao Narodnom klubu sastavljenome od hrvatskih senatora koji su „u cilju narodnog smirenja sudelovali kod režima“ ${ }^{38}$ Drugim riječima, oni se nisu slagali s načelima integralnog jugoslavenstva centralističkog tipa kakav je prevladavao, nego su ustrajavali na naglašavanju posebnih političkih individualiteta kod Srba, Hrvata i Slovenaca s obilježjima zasebnih nacija, uz shvaćanje Jugoslavije kao zajedničke domovine („naša je Država složena državna zajednica od više historijsko-političkih individualiteta, a jugoslovenstvo skupni pojam triju narodnih komponenata: srpstva, hrvatstva i slovenstva, od kojih svako u sebi posjeduje sve nacionalne atribute"). ${ }^{39} \mathrm{Na}$ tom je tragu Gjirlić nastupao $\mathrm{u}$ ime obrane pojedinih interesa za koje je smatrao da su bili povrijeđeni neravnopravnim odnosom središnjih vlasti prema hrvatskoj strani. ${ }^{40}$ Stoga je zastupao ne baš često zastupana gledišta da unitarizam nije sinonim za centralizam i da zbog toga „naš unitarizam (...) može da bude i širosamoupravni i autonomni i federalistički bez ikakove separatističke težnje“. ${ }^{41}$ Senatska većina je takve poglede odbacila, smatrajući da su oni federalističke naravi i da kao takvi slabe koheziju države, odnosno potiču nedopustivu raspravu u Narodnom predstavništvu. Gjirlić je u Senatu bio izabran u Odbor za proučavanje zakonskih prijedloga o odlaganju, izvršenju i oprostu novčanih kazni i odšteta po šumskim krivicama i o snabdijevanju siromašnih zemljoradnika i radnika na malo. Najviše pozornosti izazvao je njegov senatorski govor o pomorskom ribarstvu tijekom rasprave o proračunu Ministarstva

36 Tonći Šrtin, „Stjepan Radić i Dalmacija (1918.-1928.)“, Radovi Zavoda povijesnih znanosti HAZU u Zadru, 42/2000., 446.

37 Tonći Šrtin, „Hrvatski seljačko-radnički blok na izborima za oblasne skupštine u siječnju 1927. godine“, Radovi Filozofskog fakulteta, 25/1986., 299-318.

38 Taj je termin upotrijebio senator Želimir Mažuranić, koji je bio ministar trgovine i industrije u Živkovićevoj vladi. Vidi: Stenografske beleške Senata Kraljevine Jugoslavije, godina 2., knj. 2, Beograd 1933., 20.

39 Stenografske beleške Senata Kraljevine Jugoslavije, godina 2., knj. 3, Beograd 1933., 87.

40 Primjerice, Gjirlić je govorio 28. 3. 1933. da je u „resoru Ministarstva prosvjete učinjeno toliko toga od početka do danas na štetu Hrvata“. Usp.: Stenografske beleške Senata Kraljevine Jugoslavije. Redovan saziv za 1932 i 1933 godinu, knj. III, Beograd 1933., 157-160.

41 Posebno otisnuti Gjirlićev članak „Unitarizam i centralizam“, fond Nikole Precce, Državni arhiv u Zagrebu. 
poljoprivrede u kojemu se založio za davanje većih potpora ribarima. Pritom je predložio osnivanje samostalne i stručne uprave ribarstva u sastavu Direkcije pomorskog saobraćaja u Splitu, novi zakon o unapređenju morskog ribarstva, ustrojavanje posebne škole za ribarski pomladak, mirovinsko osiguranje, udruživanje ribara u jedinstvenu stručnu udrugu i poticanje povoljnijih beskamatnih zajmova i premija. ${ }^{42}$ Uspoređujući njegove nastupe može se zaključiti da je Gjirlić spadao među najaktivnije govornike iz hrvatskih redova, koji je pri tome iznosio i gledišta protivna senatskoj većini, zagovarajući prigodom rasprave o izmjenama i dopuna Zakona o izboru narodnih poslanika demokratizaciju izbornog sustava uvođenjem tajnog prava glasa. ${ }^{43}$ Iz dijela njegovih istupa može se zaključiti da je pokušavao javno preispitivati odnos državnog središta prema prilikama u Dalmaciji pa je tako isticao zapostavljanje njezina prometnog razvoja na primjeru sporog poticanja izgradnje Unske pruge u odnosu na zaključene ugovore s operaterom Batignollesom za izvođenje javnih radova („Pruga Kuršumlija - Priština već se punom parom radi, a pruga Bihać - Knin toliko je napredovala da još nisu otvorene kancelarije za izradu detaljnih planova...“ ). ${ }^{44}$ Kao senator održavao je kontakte s vodstvom HSS-a i A. Trumbićem, izvještavajući ih o političkim kretanjima u Beogradu. ${ }^{45}$ Biran je za narodnog zastupnika 1935. u splitskom izbornom kotaru. Tijekom rata živio je u Splitu bez političkog angažmana, ali odobravajući Mačekovu koncepciju političkog neistupanja. Prema izvorima komunističkih vlasti nakon Drugoga svjetskog rata „nezgodnije i neprijateljski istupa, zbog čega se nalazi pod kontrolom“ ${ }^{46}$

Frano Ivanišević (Jesenice kraj Splita, 1. siječnja 1863. - Jesenice, 4. lipnja 1947.) je bio istaknuti svećenik, političar i etnograf. ${ }^{47}$ Završio je Klasičnu gimnaziju u Splitu (1883.), a studij bogoslovije u Zadru (1887.). Iste je godine bio zaređen za svećenika. Obavljao je dužnost prefekta i duhovnika biskupskog sjemeništa u Splitu, a bio je i profesor u Realnoj gimnaziji, župnik u Solinu-Vranjicu te rodnim Jesenicama. Umirovljen je 1911. godine. Izabran je 1907. na izbornoj listi Narodne stranke za Carevinsko vijeće u Beču. S izbijanjem Prvoga svjetskog rata postaje dobar primjer za one katoličke svećenike koji su imali istaknutu ulogu u jugoslavenskim inicijativama. ${ }^{48} \mathrm{Na}$ narodnom zboru u Splitu imenovan je početkom srpnja 1918. u gospodarski odbor Narodne organizacije. Nakon proglašenja Kraljevstva SHS postao je jedan od istaknutijih zagovornika jugoslavenske nacionalne ideje u Dalmaciji. Prvo je vrijeme slijedom svoje potpore Hrvatskom katoličkom pokretu i njezinom ratnom glasilu Novine, oko kojeg se isticala skupina mlađeg svećenstva, podržavao Pučku stranku i u njezino ime bio je izabran za zamjenika člana Privremenog narodnog predstavništva u Beogradu. ${ }^{49}$ Sudjelovao je i u radu Kongresa javnih radnika u Zagrebu

42 Govor je objavljen i u Jadranskom dnevniku pod naslovom „Problem našeg pomorskog ribarstva“. Usp. Jadranski dnevnik (Split), br. 8., 29. 3. 1934., 6.

43 Stenografske beleške Senata Kraljevine Jugoslavije, godina 2., knj. 2, Beograd 1933., 25 i 109-111.

44 Stenografske beleskke Senata Kraljevine Jugoslavije, godina 2., knj. 3, Beograd 1933., 243.

45 Ljubo Boban, Maček i politika Hrvatske seljačke stranke 1928-1941, sv. 1, Zagreb 1974., 185-186.

46 Bivše građanske stranke u kotaru Split (elaborat o rekonstrukciji), SDS, HDA, 21.

47 Nataša BAšıć-Kosıć - Ankica Šunjić, „Don Frano Ivanišević - prinos bibliografiji“, Bibliographica (ur. Trpimir Macan), sv. 1, Zagreb 2003., 117-139.

48 Ulogu katoličkog svećenstva u jugoslavenskom pokretu za Dvojne Monarhije ističu i neki od saborskih zastupnika koji su se pred kraj rata okupili oko utjecajnog Glasa Slovenaca, Hrvata i Srba. Vidi: Drago Roksandić, Srpska i hrvatska povijest $i$ „nova historija“" Zagreb 1991., 201. 
(1922.), a u Splitu je pokrenuo i uređivao novine Pučki list, Zadrugar, Pučke novine i Pučku prosvjetu. U njima se zalagao za agrarnu reformu, modernizaciju poljoprivrede, aktivniju socijalnu politiku prema seljačkom pučanstvu i unutarnju kolonizaciju. Posebno se zanimao za promicanje ideje zadrugarstva po uzoru na Raiffeisenove seljačke zadruge. Upoznao ih je tijekom stručnih ekskurzija po južnom Tirolu, a zatim kao poželjni model prenio u svoju domovinu, što je rezultiralo osnivanjem Zadružnog saveza Dalmacije. Sustavno se zalagao za unapređenje vinogradarstva, ribarstva, turizma i zaustavljanje iseljavanja lokalnog stanovništva. Kao i kod većine drugih političkih aktivista iz Dalmacije $s$ negodovanjem je pratio način uređivanja odnosa nove države s Italijom, smatrajući da su u njima posebno zakinuti gospodarski interesi dalmatinskog područja i to naročito na području pomorskog ribarstva. Uz to se bavio proučavanjem glagoljice i staroslavenskog jezika, koji su također na kulturološkom planu bili važan dio strategije suzbijanja talijanskog utjecaja u istočnojadranskim krajevima. Njegovim zalaganjem otvoreno je 1925. Pučko sveučilište u Splitu, kojemu je bio predsjednik do 1927. Predsjedao je Jugoslavenskom maticom, a obnašao je i dužnost člana upravnog odbora Jadranske straže. Još je od ranije prikupljao etnografsko gradivo pa je tako objavio u redovima stručne javnosti vrlo dobro prihvaćenu monografiju o folkloru Poljica. Narodni život i običaji, koju je Jugoslavenska akademija znanosti i umjetnosti objavila 1903. - 1906. u Zagrebu. Nakon uvođenja šestosiječanjskog režima podržao je kraljevu politiku kao nužan potez u jačanju državnog jedinstva, a kralja je opisao kao „velikog majstora“ $\mathrm{i}$,graditelja na političko-državnom polju“.50 Pri tome je bio prepoznatljiv i njegov pogled na političku scenu po naglašavanju jugoslavenskog imena i odbacivanju starih političko-ideoloških naziva. Tako je u potonjem slučaju kritizirao osnivanje Jugoslavenske radikalsko seljačke demokracije okupljene oko predsjednika vlade Petra Živkovića jer je u nazivu te organizacije prepoznavao povratak na stare stranačke podjele - radikali, demokrati i seljaci - tako da je podržao preimenovanje u Jugoslavensku nacionalu stranku, koja je svojim imenom trebala prevladati tradicionalne podjele. ${ }^{51}$ Zato i nije bilo neobično da ga je kralj zbog takvih stavova i ugleda među širim slojevima svojim ukazom u lipnju 1933. imenovao za senatora. Taj je položaj u najvećoj mjeri iskoristio za zagovaranje gospodarskih i socijalnih interesa Dalmacije. Njegov senatski govor o proračunskoj raspravi tiskan je kao posebna brošura pod naslovom $O$ narodnom gospodarstvu na Jugoslavenskom primorju (Split, 1934.). U službenoj literaturi ocijenjen je kao jedan od „najmarkantnijih figura koje je dao unitaristički pokret u Dalmaciji“". 52 No i njegovi senatski istupi bili su popraćeni jednom epizodom iz 1938. koja ukazuje na nezadovoljstvo dijelom državne politike na vjerskom području. Riječ je o povlačenju Konkordata iz Narodnog predstavništva. Prema Ivaniševiću je zbog tog ugovora sa Svetom Stolicom „dignuta hajka na vjersko crkveno pitanje i pretvorilo ga u partijsko političko pitanje“ pa su tako „jedino Jugoslavija i Rusija“ ostali bez uređenog pitanja crkvenog odnosa s državom, a pri tome je u Senatu istaknuo

\footnotetext{
Zlatko Matijević, Slom politike katoličkog jugoslavenstva, Zagreb 1998., 131.

50 Frano IvanišEvić, „Jugoslavenska narodna stranka“, Pučka prosvjeta, 12/1932., br. 7, 146.

51 Isto.

52 Čedomil M. Mitrinović (ur.), Biografski leksikon. Narodno pretstavništvo, Beograd 1935., 29.
} 


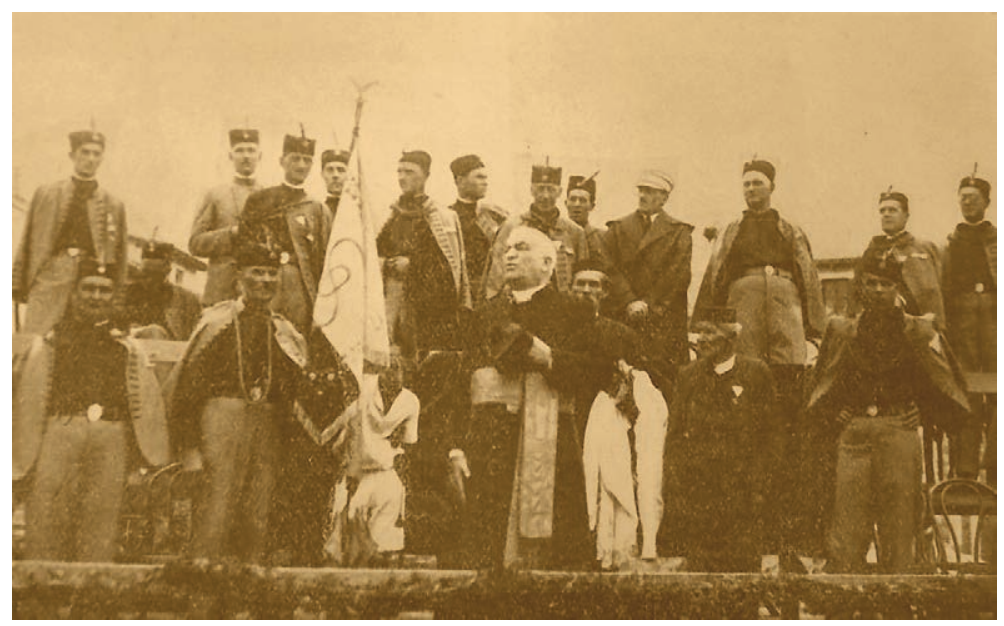

Sl. 5. Don Frano Ivanišević blagoslivlja barjak na sokolskom slavlju u Vranjicu u kolovozu 1931.

držanje nadbiskupa Stepinca, koji je pozvao katoličko svećenstvo i pučanstvo da odustanu od priređivanja protestnih skupština čime je pridonio smirivanju napete situacije. ${ }^{53}$

Drugi po kronološkom redu izabrani senator bio je Ivo Majstrović (Dragljane kod Vrgorca, 14. rujna 1868. - Split, 7. rujna 1947.). U dijelu literature često se krivo navodi kao Majstorović, što samo po sebi ukazuje na površnost istraživanja vremena u kojemu je nastupao taj za dalmatinske prilike neosporno istaknuti političar. On je pohađao gimnaziju u Splitu. Studirao je pravo u Zagrebu i Grazu, gdje je stekao doktorat (1896.). Odvjetničku karijeru započeo je u Pazinu u uredu Dinka Trinajstića, ujedno istaknutog istarskog političara iz Krka, kojega je kasnije jugoslavenski kralj imenovao senatorom, a zatim je otvorio vlastiti ured u Splitu. Prije Prvoga svjetskog rata zastupao je izborne kurije Vrgorac, Makarska i Metković u pokrajinskom Dalmatinskom saboru u Zadru (1901. - 1908.). U to je vrijeme bio član dalmatinske Čiste stranke prava, kasnije preimenovane u Stranku prava, u kojoj je bio po svom saborskom zastupstvu i član njezinog izvršnog odbora. ${ }^{54}$ Objavio je brošuru Besjeda biračima pri pohodu izbornog kotara (Zadar, 1903.) i niz članaka u dalmatinskoj i primorskoj periodici (Novi viek, Hrvatska kruna, Novi list, Hrvatska rieč) u kojima je iznosio svoje poglede o aktualnim problemima. Jedan je od potpisnika manifesta protiv zemaljske uprave bana Khuena-Héderváryja u Banskoj Hrvatskoj i sudionik protestne delegacije sastavljene iz redova dalmatinskih zastupnika u Beču tijekom narodnih nemira 1903. godine, čime je započela šira koncentracija političara u sklopu „novoga kursa“. Sudjelovao je u redigiranju Riječke rezolucije (1905.), ali se poslije donošenja ogradio od načina njezine primjene. U javnom životu se isticao kao jedan od vodećih pripadnika dalmatinskog sokolstva, čiji je bio predstavnik na velikom I. hrvatskom svesokolskom sletu u Zagrebu (1908.). ${ }^{55}$ Na početku Prvoga svjetskog rata uzet je za taoca. U ljeti 1918. imenovan je za

$\overline{53}$ Stenografske beleške Senata, god. 7., knj. 1, Beograd 1938., 208. Govor je održan 24. 3. 1938. Drugačije mišljenje, uz opasku da se katolička hijerarhija nije „nikada zagrijala za Jugoslaviju“, iznio je senator Majstrović u članku „Prilog Jugoslavenskom ultramontizmu“, Narodni list (Split), br. 46, 21. 11. 1940., 1.

54 Više vidjeti u: Marjan Diklić, Pravaštvo u Dalmaciji do kraja prvoga svjetskog rata, Zadar 1998. 
člana uprave Narodne organizacije SHS, koja je preuzela vođenje političkog pokreta u Dalmaciji i povezala ga s Narodnim vijećem SHS. U tom prijelaznom razdoblju obavljao je dužnosti vijećnika Općinskog vijeća grada Splita (od studenog 1918.), člana disciplinskog suda Općinskog vijeća te voditelja Narodne garde. Nakon osnivanja Kraljevstva SHS pristupio je Demokratskoj stranci u kojoj je bio predsjednik njezinog Pokrajinskog odbora u Dalmaciji, a kasnije voditelj organizacije u Splitu te je u tom svojstvu održavao kontakte sa stranačkim vodstvom u Beogradu. Prigodom dolaska Ljube Davidovića u Split zagovarao je dovršetak izgradnje Ličke pruge i dosljednu primjenu općinskih samouprava. Blisko je surađivao sa splitskim načelnikom i kasnijim banom Primorske banovine Ivom Tartagliom. Na općinskim izborima zajedno su nastupali u Bloku građana i

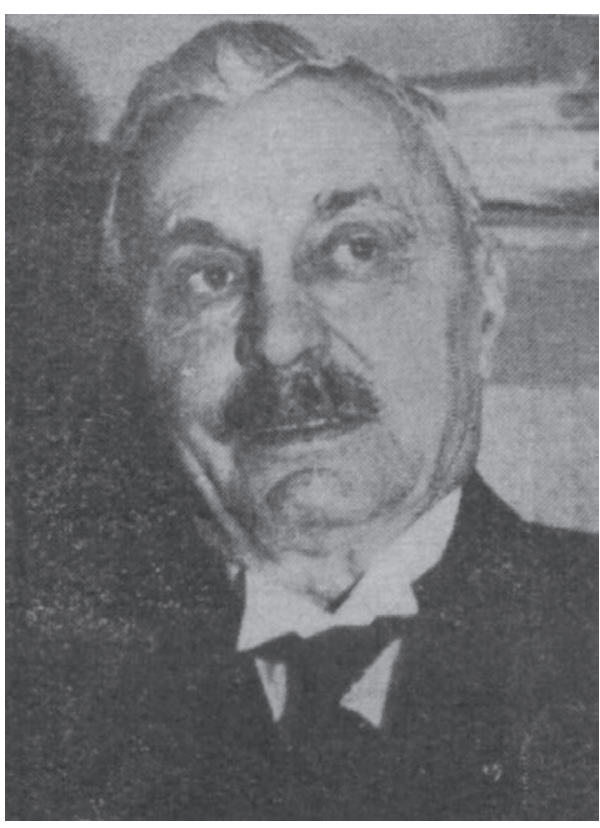

Sl. 6. Ivo Majstrović seljaka. Opravdavao je suspenziju ustavnosti nakon skupštinskog atentata u prilog državnog jedinstva, s time da je osuđivao rigorozan postupak cenzure štampe i zagovarao veću autonomiju ustrojenih banovina. Njegova tvrda lojalnost šestosiječanjskom režimu očitovala se u izjavi da je narod „okupljen pod zastavom svog velikog Kralja i Vođe (...) uvjeren da je svoju Golgotu prebrodio, svrstao se je u jaku nacionalističku falangu, da stupa prema svojoj sretnoj i vedroj budućnosti“ “.56 Osobito je sustavno govorio protiv prijetnji talijanskih pretenzija na Jadransko more i ukazivao na opasnosti vanjske politike fašističke vlade u Rimu. Pred takvim iskušenjima zalagao se za okupljanje oko „jedne velike misli i velike ličnosti“.

Predlagao je u Senatu repatrijaciju iseljenika iz prekooceanskih zemalja koji su zbog ekonomske krize izražavali želju za povratkom u domovinu. U stranačkom smislu bio je predsjednik akcijskog odbora za organizaciju Jugoslavenske radikalno seljačke stranke za Primorsku banovinu, a od 1935. član njezine sljednice Jugoslavenske nacionalne stranke, na čijoj je listi osvojio iste godine mandat narodnog zastupnika. U senatorskom govoru iz ožujka 1934. naglasio je da je „pametna politika razborito, čestokrat kompromisno prilagođivanje realnim prilikama u pozitivnom i aktivnom radu za očuvanje i unapređenje vlastitih interesa u jednoj kolektivnosti“ nasuprot politike pasivne rezistencije Hrvatske seljačke stranke. Na temelju takvih pogleda jasniji su razlozi njegova zagovaranja autoritativnog režima na zasadama „Januarskog Manifesta“, ali i zahtjeva za decentralizacijom

55 Ivan MajSTrović, „Prigodom VII. Sokolskog Župskog Sleta u Splitu“, Novo doba (Split), br. 205, 5. 9. 1926., 2. Za vrijeme senatskog mandata govorio je o potrebi poticanja jugoslavenskog sokolstva i povećanju proračunskih sredstava za fizički odgoj. Stenografske beleške Senata Kraljevine Jugoslavije, god. 2, knj. 3, Beograd 1933., 196-200.

56 Ivan Majstrović, „Jugoslavenski nacionalizam jedini je kadar i pozvan, da riješi sva naša narodna pitanja i sporove“, Seljački kalendar za godinu 1936, Split, s. d., 80-81. 
državne uprave putem općinskih i banovinskih samouprava. Njegova privrženost jugoslavenstvu bila je neupitna. U Kraljevini Jugoslaviji vidio je srednjoeuropsku, balkansku i sredozemnu državu koja u tadašnjoj Europi „pretstavlja prepreku za prodiranje boljševizma na zapad, pangermanizma preko Balkana na istok i fašističkog imperijalizma prema Dunavu i Istanbulu“. 57 Nakon proglašenja Banovine Hrvatske podnio je ostavku na članstvo u splitskoj Čitaonici, koja se preimenovala iz Jugoslavenske u Hrvatsku. Prema izvorima Službe državne sigurnosti za vrijeme Drugoga svjetskog rata nastavio je živjeti u Splitu, a djelovao je „na strani četništva“.58

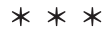

Biografije senatora pokazuju dosta zajedničkih poveznica bez obzira na njihove različite ranije stranačke pripadnosti i međusobna neslaganja oko interpretacije pojedinih aktualnih problema. Primjerice, budući senatori Desnica, Ivanišević i Majstrović djelovali su na kraju Prvoga svjetskog rata u Narodnoj organizaciji SHS za Dalmaciju, dok je Angjelinović imao istaknutu ulogu sa skupinom Dalmatinaca u zagrebačkom Narodnom vijeću SHS. Izuzevši Gjirlića, sva su četvorica imala vrlo zapažene uloge u pokretu koji je pri kraju rata organizirano vodio borbu protiv Habsburške Monarhije („austrijanštine“) i prema ustrojavanju Kraljevstva SHS na načelima zastupanja ideje narodnog jedinstva. ${ }^{99} \mathrm{U}$ toj ideji vidjeli su poveznicu između Hrvata i Srba, koje je bilo osobito naglašeno zbog potrebe otpora talijanskom zaposjedanju većih dijelova Dalmacije. Ivanišević i Gjirlić bili su rimokatolički svećenici i u skladu s time nisu imali afiniteta prema „naprednjačkim“ ili modernijim liberalnim idejama kakve su znali zastupati drugi senatori. No, oba su svećenika, svaki na svoj način, prihvatili jugoslavenski nacionalni identitet. Prvi je kontinuirano bio jugoslavenski opredijeljen, dok je drugi to naglašeno prihvatio nakon uspostave diktature. Njima uz bok možemo pribrojiti i Desnicu kad je riječ o sustavnom raspravljanju agrarnog pitanja jer su sva trojica zamjetnu pozornost posvetila problemu poslijeratne raspodjele zemljišta i prosvjećivanja sela, a pri tome su kao i ostali senatori upozoravali na prijetnje boljševizacije društva što i nije bilo neobično zbog konzervativnije naravi svih senatora. ${ }^{60}$ Skoro svi su u sklopu rasprava o državnom proračunu isticali potrebe poticanja razvoja Splita i šire okoline u rasponu od osnivanja Oceanografskog instituta i podizanja bolnice na Firulama do

57 Isto, 197.

58 Bivše građanske stranke u kotaru Split (elaborat o rekonstrukciji), Služba državne sigurnosti (SDS), Hrvatski državni arhiv (HDA). Taj podatak možemo usporediti i s Majstrovićevim govorom u Senatu u kojemu je rekao: „Nijedan jugoslovenski patrijota ne može da odreče ispravnost programa i rada organizacijama, kao što su četnička, streljačka, ratnička i invalidna udruženja ..." Stenografske beleške, god. 2, knj. 3, Beograd 1933., 200.

59 Zamjetno je da su mnogi od njih u svojim interpretacijama povijesti ukazivali na genezu jugoslavenske ideje i potrebu uzajamnog rada kroz djelovanje iliraca, biskupa Strossmayera i dalmatinskih „narodnjaka“: „Štrosmajer“, Država (Split), br. 184, 3. 2. 1926., 1; Govor senatora Frana Ivaniševića u budžetnoj raspravi, „Na Jadranu je budućnost Jugoslavije“, Država (Split), br. 11, 25. 3. 1937., prilog.

60 Desnica je u jednom članku iz ranijeg razdoblja naveo suradnju s Gjirlićem u nastojanjima da se pomogne ekonomskom podizanju sjeverne Dalmacije, navlastito Ravnim Kotarima, i oslobodi ga se posljedica malarije. Dr. U. D. „Za spas jednog kraja“, Država (Split), br. 157, 24. 10. 1925., 1. 
sustavnijeg podupiranja ribarstva, pomorstva i poljodjelstva, dok je Desnica posebnu pozornost usmjeravao i rodnom zavičaju u sjevernoj Dalmaciji. A u zastupanju pogleda na lokalne potrebe dobro im je došlo iskustvo koje su prikupili u svojem radu u općinskim tijelima i oblasnoj skupštini. Ako u obzir uzmemo i trojicu imenovanih senatora (Račić, Smodlaka i Tartaglia), koji su to bili samo u formalnom smislu jer iz objektivnih razloga više nisu mogli nastupati u Senatu, ta se kontinuirana privrženost jugoslavenskom državnom okviru još više očitovala. Unatoč različitim stranačkim ili nekim drugim ideološkim pripadnostima upravo je taj pozitivni odnos prema jugoslavenstvu bio njihov zajednički nazivnik koji je na određeni način i proturječan jer je dio njih prva iskustva stjecao u sklopu pravaških stranka (Majstrović, Angjelinović, Gjirlić), a raspadom Austro-Ugarske posve je odbacio takav tip ideologije. ${ }^{61} S$ druge strane, pojedinosti iz njihovih životopisa svjedoče o promjenama raspoloženja koja su bila određena teškom situacijom, osobito za vrijeme različitih napetosti u Kraljevini Jugoslaviji i za nju nepovoljnim utjecajima vanjsko-političkih okolnosti. Kao znakovit primjer može se uzeti novinska polemika između Angjelinovića i Desnice koja je izbila zbog govora drugoga prigodom debate o proračunu Ministarstva unutarnjih poslova. Iz Desničinog istupa, koji je - kako je i sam naglasio - bio jedan od njegovih rijetkih govora u Senatu, mogle su se uočiti dvije važne činjenice. Prva je bila tehničke prirode i jasno je upućivala javnost da su naknadno sastavljeni i objavljeni stenografski zapisnici Senata „nepotpuni i netačni“ pa je tako zbog pomanjkanja integralnog teksta govora moglo lako doći do nesporazumijevanja koja su poticala rasprave u javnosti. ${ }^{62}$ Riječ je o opaski koja je osobito važna za povjesničare jer je ona mogla značiti da su naknadne intervencije u govore senatora znale utjecati i na izrečene sadržaje. Druga je ipak upućivala na dublje korijene razmimoilaženja i to napose u političkom krugu koji je načelno trebao biti homogen. Naime, Desnica je u senatskom govoru zapravo reagirao na istup senatora Gjirlića, koji je osudio korištenu represiju državnih organa u pojedinim mjestima srednje i sjeverne Dalmacije. ${ }^{63}$ Desnica je u svom nastupu učinio suprotno. Branio je postupke policije i žandarmerije, smatrajući da su oni bili ponajprije posljedica suzbijanja aktivnosti ustaške emigracije, koja je preko Zadra i sjeverne Dalmacije krijumčarila oružje. Gjirlićev govor smjestio je u kampanju koju iskorištavaju fašistički listovi u Italiji za svoje interese da bi prikazali situaciju u zapadnim dijelovima Jugoslavije nepovoljnom. Njegovo je izlaganje bilo nadalje obrazloženo obranom državnog odnosa prema tim dijelovima Dalmacije, zbog čega je često bio na udaru kritika iz hrvatskih redova. Tako je iznio podatke o državnim ulaganjima u javnu infrastrukturu na području sjeverne Dalmacije i naveo provedbu akcija protiv suzbijanja malarije, s posebnim naglaskom na općine u kojoj su Hr-

$\overline{61}$ Jedan od primjera nudi sačuvana korespondencija Milana Ćurčina, koja ukazaje da je on u svojstvu izdavača Nove Evrope pozivao na suradnju Uroša Desnicu. Ćurčin je kao izdavač Nove Evrope zastupao specifične poglede na problem konsolidacije Jugoslavije (tzv. srednja linija), a među njegovim bliskim suradnicima bio je i budući senator Ivo Tartaglia. Vidi pismo Vladana Desnice uredniku Nove Evrope, Split 7. 12. 1932., Nacionalna i sveučilišna knjižnica, Zagreb, R 7446 b.

62 „Šta je senator g. dr. Uroš Desnica govorio o narodu u Dalmaciji. Odgovor dr. Grgi Anđelinoviću. (Split, 11. aprila 1933.)“, Politika (Beograd), br. 8953, 14. 4. 1933., 2.

63 Stenografske beleške Senata Kraljevine Jugoslavije. Redovan saziv za 1932 i 1933 godinu, knj. III, Beograd 1933., 178182. Govor je održan 29. 3. 1933. 
vati bili većina, a nije propustio ni protumačiti razloge unutarnjih sukoba koji su se odnosili na poglavito hrvatski otpor prema vladajućoj politici u Kraljevini Jugoslaviji. Prema Desnici, radilo se u tom sukobu o psihološkom problemu koji je bio odraz podjele na „istočni i zapadni dio naroda“. Drugim riječima, tok povijesti uvjetovao je razlike pa je tako ovaj splitski senator istaknuo da je „tursko ropstvo, surovo i okrutno, očeličilo istočni deo našeg naroda u nacionalnoj svesti i otpornosti i da je to bilo silno potpomognuto od nacionalne crkve, dok je civilizovano mletačko i austrijsko robovanje, koje nije nabijalo na kolac telo, već zarobljavalo dušu, uspavalo narodne energije, skršilo otpor u narodu, oslabilo njegovu nacionalnu svest i napravilo nacionalne evnuhe ${ }^{.64} \mathrm{U}$ tom je smislu postavio pitanje zašto se baš tada pojavila u „akutnoj formi težnja za slobodnom i samostalnom Hrvatskom koja je praćena violentnim oblicima“, dok takvih pojava nije bilo pod austrijskom upravom. Dio krivnje je prebacio na vlade od 1918. nadalje jer nisu znale razviti kod svih svojih pripadnika svijest o državi, a u tom kontekstu je iznova upozorio na demagoško nasljeđe Stjepana Radića, koji je, prema njegovu shvaćanju, znatno pridonio stvaranju lažne predstave o svemoći naroda. Govorio je i o državnim potezima koji su doveli do „zvaničnog stvaranja boljševizma“ $i$ istovremene „pauperizacije buržoazije“ što se odnosilo na primjenu Zakona o agrarnim odnosima u Dalmaciji. Nije zaobišao ni očito vrlo utjecajan vjerski aspekt, tvrdeći da je „sojedinjenje crkov“" o kojoj je puno slušao u mladosti utopija i da je rješenje u „trpeljivosti crkava“, ali da on ne vidi trpeljivost kod katoličke strane. Ovime je Desnica potaknuo još jednu u nizu rasprava o tome što je tada doista bilo jugoslavenstvo, na koji se način primjenjivalo u stvarnosti i kako se ono odražavalo na nacionalno integracijske procese Hrvata i Srba, a njegova je pozicija bila obrana postojeće države i poticanje stvaranja novog tipa jugoslavenstva. Činjenica da je svoj senatski govor završio latinskom poslovicom Salus rei publicae suprema lex est govorila je o tome u kojoj je mjeri on procjenjivao narušene odnose u Kraljevini. Naknadno uključivanje u raspravu Angjelinovića, koji je javno prozvao Desnicu da je u senatskom nastupu tendenciozno govorio o Hrvatima i političkoj prošlosti Dalmacije, čime je povrijedio načela jugoslavenske politike i stavio u težak položaj Hrvate jugoslavenske orijentacije, upućivalo je na poremećene odnose u Senatu. ${ }^{65}$ Angjelinovićevo javljanje mora se promatrati u kontekstu njegova rukovodećeg položaja u Jugoslavenskoj nacionalnoj stranci i shodno tome prepoznatljive težnje da se ne pogoršava stanje u onome političkom okruženju za koje se očekivalo da će provoditi kraljeve težnje izrečene u njegovu šestosiječanjskom proglasu. Ta je stranka sa svojom bezuvjetnom potporom režimu (,vjerni pomagači“) bila važan čimbenik u provođenju Oktroriranog ustava i stoga su unutarnji sporovi mogli utjecati na ocjenu da je njezin položaj neispravan i da ona možda nije dovoljno snažna za sudjelovanje u vladi. S obzirom da je JNS imenovanjem Jevtića za predsjednika vlade pala u drugi plan, a sa Stojadinovićevom vladom još više izgubila na značaju, pokazala su se opravdanim Angjelinovića strahovanja za budućnost njegove stran-

$\overline{64}$ „Šta je senator g. dr. Uroš Desnica govorio o narodu u Dalmaciji. Odgovor dr. Grgi Anđelinoviću. (Split, 11. aprila 1933.)“, Politika (Beograd), br. 8953, 14. 4. 1933., 2 i Stenografske beleške, knj. III, 180. Desničin opis govora koji je objavio u Politici nešto je izmijenjen u odnosu na govor zabilježen u Stenografskim beleškama.

65 Dr. B. G. AnĐelinović, „Šta je senator g. dr. Uroš Desnica rekao o narodu u Dalmaciji (Beograd, 4. aprila 1933.)“, Politika (Beograd), br. 8948 , 9. 4. 1933., 4. 
ke. Međutim, navedena debata unatoč svojoj britkosti nije izazvala prekid odnosa među njezinim sudionicima. O tome svjedoče činjenica da je Desnica jedno vrijeme podržavao JNS i sam se smatrao Angjelinovićevim „partijskim drugom“ uz kojega je stajao i za vrijeme provođenja općinskih izbora u Primorskoj banovini. ${ }^{66}$ Ta je suradnja izazvala sukobe unutar jugoslavenski orijentiranog dijela političke arene u Dalmaciji jer su tamošnji radikali prvi izražavali uvjerenje da Desnica zbog svoje prošlosti ne će podržati JNS i time postati „politički skakavac“. ${ }^{67} \mathrm{Kad}$ je postalo jasno da je do te suradnje došlo, onda su radikali komentirali da je time Angjelinović iskoristio Desnicu za provođenje izborne akcije među srpskim elementom. ${ }^{68}$ Kasnije su Angjelinović i Desnica zajedno nastupali u svečanim prigodama, uz ostale splitske senatore, bili članovi brojnog Oblasnog odbora za otkriće spomen-svjetionika Kralju Aleksandru u Splitu i prigodom porinuća dvaju brodova u splitskom Jadrankom brodogradilištu. Novine će zabilježiti da će u izbornoj 1938. Desnica napustiti JNS i na sastanku sjevernodalmatinskih Srba u Šibeniku podržati kandidate Jugoslavenske radikalne zajednice (JRZ). ${ }^{69}$ Upravo su parlamentarni izbori 1938. ukazali na prevlast Hrvatske seljačke stranke i na dalmatinskom području, a sporazum Cvetković Maček označio je posljednji pokušaj prije izbijanja rata da se riješe unutrašnji problemi. Stvaranje Banovine Hrvatske, u kojoj je Split bio drugi grad po veličini, utjecat će na dinamizaciju političkih kretanja i jače uključivanje ilegalnih organizacija različitih ideoloških usmjerenja. ${ }^{70}$ Pri tome se većina senatora držala po strani, a neki su se tek povremeno javljali preko tiska. Bili su svjesni opadanja svojeg značaja budući da više nisu imali političku snagu kakvu su uživali prije promjena. Iz tih se tekstova može zaključiti ono što je rekao slovenski senator Ivan Pucelj, također član JSN-a: neprijatno je stati iza sporazuma s HSSom, ali to je ipak najbolje s obzirom da Maček legitimno stoji na čelu hrvatske strane. Službena izvješća govorila su o „umrtvljenju“JNS-a i JRZ-a, no i dalje su izlazila njihova glasila, koja su pozorno i sa strepnjom pratila novonastale odnose u Kraljevini Jugoslaviji i utjecaje vanjsko-političkih kretanja koja su postupno uvukla Europu u rat. Vodstva tih dviju stranaka lojalno su podržala Banovinu u nadi da će njezine vlasti provoditi model hrvatske politike na bazi jugoslavenske ideologije i time im ostaviti manevarski prostor.

Da zaključimo. Ovaj članak pokušaj je isticanja potrebe za iscrpnijim proučavanjem života i političkih veza parlamentarnih zastupnika. Tako zamišljeni prozopografski pristup nameće se kao neizbježna historiografska zadaća jer bez toga nije moguće shvatiti poteze onih aktera koji su imali istaknutu ulogu, u ovom slučaju, u političkim kretanjima Dalmacije tijekom druge polovice međuratne Jugoslavije. U središte pozornosti stavljeni su senatori koji su, bez obzira na način svog izbora ili imenovanja, prednjačili u problematiziranju

$\overline{66}$ U prvom broju novopokrenutog Narodnog lista, koji se predstavio kao glasilo jugoslavenskih nacionalista iz Banovine Hrvatske i bio je u Angjelinovićevu vlasništvu, Desnica je objavio članak „Osvrt na prošlost - pouka za budućnost“ (br. 1, 1. 11. 1939., 1). U njemu je naznačio povijesnu važnost stvaranja jugoslavenske države i poručio da će sporazum Cvetković - Maček morati pokazati je li za nju „pobjedna pjesma“ ili „pogrebno zvono“.

68 „JNS se raspada“, Država (Split), br. 37, 22. 10. 1936., 3.

69 „Zaključci JNS iz sjeverne Dalmacije“, Država (Split), br. 53, 15. 11. 1938., 3.

70 O tome podrobnije u feljtonu Fikrete Jelić-Butić, „Banovina Hrvatska. Političke prilike na području Ispostave banske vlasti u Splitu 1939.-40. godine“, Slobodna Dalmacija (Split), br. 14313 - br. 14330, 6. - 23. 10.1990. 
niza unutarnjih i vanjskopolitičkih tema. Unatoč vezanosti senatora uz ideologiju jugoslavenstva i neupitnoj lojalnosti prema vladajućoj dinastiji, senatske rasprave i njihovi odjeci u lokalnom ambijentu ukazivali su na različite načine promišljanja. Suočeni s dubokom državnom krizom nastojali su artikulirati svoje političke zahtjeve kojima su pokušavali pomiriti gospodarsko-socijalne interese Dalmacije sa širim okvirom, ali i istaknuti svoja individualna gledišta, koja su postajala sve teže izvediva zbog slabljenja njihova osobnog utjecaja.

\section{$\cos$}

\section{Senators from Split: Coming to Terms with the Crisis of Yugoslavia and Yugoslavdom}

The author chronologically elaborates the activities of politicians from Split and its surroundings (Grga Angjelinović, Uroš Desnica, Petar Gjirlić, Frano Ivanišević and Ivan Majstorović) who entered or were appointed to the Yugoslav Senate according to paragraph 32 of the Constitution after the January $6^{\text {th }}$ dictatorial regime. These were members of several political parties and currents of Yugoslav orientation whose public personas during the 1930s gained new affirmation in the Senate with the setting up of the Littoral Banovina. At the time Split was a central point of the coastline and a rich political life developed which in many ways mirrored the one during late Austria-Hungary and the challenges at the end of World War One when Italian plans for expansion to the east Adriatic became a reality. The poor experience with Austrian authorities and Italian threats helped homogenize the political scene so that a larger number of the public elite among Croats and Serbs acted in unison during the proclamation of the Kingdom of Serbs, Croats and Slovenes. On the other hand, by analyzing their public speeches the author points to their discordant approaches to a solution of the state crisis, judgments on national leaders such as S. Radić and N. Pašić, relations between church and state, interpretations of socio-economic issues and questions regarding national identity. Throughout this, the local circumstances and personal views of the senators follow their worldviews which ranged from conservatism to radical liberalism. In this sense the senators belonged to different political parties leading up to the January $6^{\text {th }}$ dictatorship which led them into many arguments during National, municipal and county assembly elections in Split. Alongside this, many of them took part in the schisms that befell the great parliamentary parties in which their careers began. However, the common trait of all the senators was their loyalty to the ruling dynasty, the Yugoslav state and Yugoslav nationalism. Therefore, their senatorial speeches contained no criticisms of the king's dictatorship as they felt that it had been an inevitability that saved the state from internal struggles and external pretensions. The Cvetković - Maček agreement marked a turning point in their political stances, alongside the establishment of the Croatian Banovina which incorporated the Littoral Banovina. Their earlier integralist attitudes shifted and they became more open towards the possibility of a Croatian and Serbian agreement as a key for resolving the Yugoslav crisis and maintaining the principle of popular unity they espoused. The author also looks into the careers of the last non-appointed senators (Jakša Račić, Ivo Tartaglia and Josip Smodlaka). They are characteristic figures because their stances evolved towards a more lenient concept of national integration which was still opposed to ideas that might disintegrate the Yugoslav state.

Keywords: Split, Senators, Yugoslavism, National integralism 


\section{$\cos$}

\section{Izvori}

Bivše građanske stranke u kotaru Split (elaborat o rekonstrukciji), Služba državne sigurnosti, Hrvatski državni arhiv

Građanske stranke i društva, grupa VII, Hrvatski državni arhiv

Fond Milana Ćurčina, Nacionalna i sveučilišna knjižnica, Zagreb, R 7446 b

Fond Nikole Precce, Državni arhiv u Zagrebu

Stenografske beleške Senata Kraljevine Jugoslavije, Beograd 1932. - 1939.

\section{Literatura}

Jovo BAKIĆ, „Nova Evropa: između prečanskog integralnog i hrvatskog minimalnog jugoslovenstva“, Nova Evropa 1920-1941. Zbornik radova (ur. Marko Nedić i Vesna Matović), Beograd 2010., 108-121.

Nataša BAŠIĆ-Kosıć - Ankica ŠunjIĆ, „Don Frano Ivanišević - prinos bibliografiji“, Bibliographica (ur. Trpimir Macan), sv. 1, Zagreb 2003., 117-139.

Ljubo BoвAn, Maček i politika Hrvatske seljačke stranke 1928-1941, sv. 1, Zagreb 1974.

Milica Bodrožıć, „Obrazovanje Jugoslovenske radikalno-seljačke stranke“, Istorijski glasnik, br. 2-3, Beograd 1964., 39-95.

Ante Bralić, „Zadarski fin de siècle - političke i društvene prilike u Zadru i Dalmaciji uoči Prvoga svjetskog rata", Časopis za suvremenu povijest, 39/2007., br. 3, 731-775.

Tihomir Cipex - Stjepan Matкović, Programatski dokumenti hrvatskih političkih stranaka i skupina 1842. - 1914., Zagreb 2006.

Dalibor ČEpulo, Hrvatska pravna povijest u europskom kontekstu, Zagreb 2012.

Ferdo Čulinović, Jugoslavija između dva rata, knj. II, Zagreb 1961.

Marjan Diklić, Pravaštvo u Dalmaciji do kraja prvoga svjetskog rata, Zadar 1998.

Stevo Djuraskovic, Fascism in Central Europe: The Organisation of the Yugoslav Nationalists-Orjuna, 1921-1929, magistarski rad, Budimpešta 2007.

Branislav Gligorijević, „Organizacija jugoslovenskih nacionalista“, Istorija XX veka, knj. V, Beograd 1963., 315-396.

Frano Ivanišević, Narodni preporod u Dalmaciji, Split 1932.

Aleksandar JaKIR, Dalmatien zwischen den Weltkriegen, München 1999.

Aleksandar JAKIr - Norka Machiedo-Mladinić (ur.), Izabrani spisi Ive Tartaglie, Split 2013.

Fikreta Jelić-Butić, „Banovina Hrvatska. Političke prilike na području Ispostave banske vlasti u Splitu 1939.-40. godine“, Slobodna Dalmacija (Split), br. 14313, 6. 10. 1990., 43; br. 14314, 7. 10., 25; br. 14315, 8. 10., 25; br. 14316, 9. 10., 27; br. 14317, 10. 10., 23; br. 14318, 11. 10., 30; br. 14319,12 . 10., 23; br. 14320, 13. 10., 43; br. 14321, 14. 10., 25; br. 14322, 15. 10., 24; br. 14323, 16. 10., 27; br. 14324, 17. 10., 30; br. 14325, 18. 10., 30; br. 14326, 19. 10., 23; br. 14327, 20. 10., 41; br. 14328, 21. 10., 24; br. 14329, 22. 10., 27 i br. 14330, 23. 10., 27.

Vladan Jovanović, „Članovi porodice Desnica u jugoslovenskim enciklopedijama i leksikonima“, Dijalog povjesničara - istoričara, knj. 9 (ur. Hans-Georg Fleck i Igor Graovac), Zagreb 2005., 243-257.

Gordana Krivokapić-Jović, Oklop bez viteza. O socijalnim osnovama i organizacionoj strukturi Narodne radikalne stranke u Kraljevini Srba, Hrvata i Slovenaca (1918-1929), Beograd 2002. 
Anatolij Kudrjavcev, Ča je pusta Londra..., Split 2002.

Norka Machiedo Mladinić, Jadranska straža, Zagreb 2005.

Norka Machiedo Mladinić, Životni put Ive Tartaglie, Split 2001.

Zlatko Matijević, „Narodno vijeće Slovenaca, Hrvata i Srba u Zagrebu“, Fontes, 14/2008., 35-66.

Zlatko Matijević, Slom politike katoličkog jugoslavenstva, Zagreb 1998.

Čedomil M. Mitrinović (ur.), Biografski leksikon. Narodno pretstavništvo, Beograd 1935.

Grga Novak, Naše more, Zagreb 1932.

Momčilo PAvlović (prir.), Istorija gradanskih stranaka u Jugoslaviji 1918-1945. Tom 1, Beograd 2008., 352-360.

Vjekoslav Perica, „Međunarodna misija u Splitu nakon Prvoga svjetskog rata“, Časopis za suvremenu povijest, 42/2010., br. 1, 127-156.

Bogdan Radica, Živjeti nedoživjeti, knj. 2, München - Barcelona 1984.

Jakša Ravlić (ur.), Zadar: Geografija, ekonomija, saobraćaj povijest, kultura, Zagreb 1964.

Drago RoKsandić, Srpska i hrvatska povijest i „nova historija“, Zagreb 1991.

Josip Smodlaka, Zapisi dra Josipa Smodlake (ur. Marko Kostrenčić), Zagreb 1972.

Tonći ŠItıN, „Hrvatski seljačko-radnički blok na izborima za oblasne skupštine u siječnju 1927. godine“, Radovi Filozofskog fakulteta, 25/1986., 299-318.

Tonći Šitin, „Prodor i pobjeda HSS-a u Dalmaciji (1923.-1928.)“, Radovi Zavoda za hrvatsku povijest, 32-33/1999. - 2000., 309-320.

Tonći ŠItin, „Stjepan Radić i Dalmacija (1918.-1928.)“, Radovi Zavoda povijesnih znanosti HAZU u Zadru, 42/2000., 431-478.

\section{Periodika}

Dalmatinski glasnik (Split)

Dalmatinski radikal (Šibenik)

Država (Split)

Jugoslovenski glas (Zagreb)

Narodni list (Split)

Novo doba (Split)

Odvjetnik (Zagreb)

Politika (Beograd)

Pučka prosvjeta (Split)

Riječ (Zagreb)

Seljački kalendar (Split) 